\title{
Evaluation of ethnobotanical knowledge in Komkar-Adi Biocultural Landscape of Eastern Himalayan Region of India
}

\author{
MOMANG TARAM ${ }^{1, \vartheta}$, DIPANKAR BORAH ${ }^{1,2, \vartheta}$, PURANJOY MIPUN $^{3}$, VIJAY TARAM ${ }^{4}$, \\ ABHAYA PRASAD DAS ${ }^{1}$ \\ ${ }^{1}$ Department of Botany, Rajiv Gandhi University. Rono Hills, Doimukh 791112, Arunachal Pradesh, India \\ "email: dipankar.borah@goalparacollege.ac.in \\ ${ }^{2}$ Department of Botany, Goalpara College. Goalpara 783101, Assam, India \\ ${ }^{3}$ Department of Botany, BN College. Dhubri 783323, Assam, India \\ ${ }^{4}$ Forum for Siang Dialogue. Pasighat, East Siang District 791102, Arunachal Pradesh, India
}

Manuscript received: 28 September 2020. Revision accepted: 25 October 2020.

\begin{abstract}
Taram M, Borah D, Mipun P, Taram V, Das A.P. 2020. Evaluation of ethnobotanical knowledge in Komkar-Adi Biocultural Landscape of Eastern Himalayan Region of India. Biodiversitas 21: 70-87. The present study was aimed to document the traditional ethnobotanical knowledge in Komkar-Adi Biocultural Landscape of Upper Siang District in Arunachal Pradesh (Eastern Himalaya), India. Data was collected from three villages of Geku circle, Upper Siang District, between 2016-2019, covering more than 50\% of the households using semi-structured questionnaires, personal interviews, focused group discussions, and transect walk with the core respondents. A total of 301 taxa falling in 203 genera and 85 families are recorded from the Komkar-Adi Biocultural Landscape (KABL), invariably used as food, medicine, and cultural material are directly and indirectly linked with livelihood security, community survival, protection, and preservation of the traditional culture and nature. Use value (UV) of all the reported species ranges between 0.017 and 0.051. 48 ethnomedicinal plant species were recorded, including herbs, shrubs, and trees, to cure 35 different ailments. Comparison of three other indices CI, RFC, and RI, indicating species ranking based on each index and the three fundamental values of the study, viz. FC, UR, and NU for each species were also calculated. Urtica dioica, Solanum spirale, Paris polyphylla, Curcuma longa, Clerodendrum colebrookeanum, and Begonia silletensis are essential for treating different ailments by the community.
\end{abstract}

Keywords: Conservation ethics, ethnobotany, Komkar-Adi, quantitative approach, traditional knowledge

\section{INTRODUCTION}

The Himalayas, also referred to as 'the abode of snow,' is the youngest and the tallest mountain ranges in the world, running over $2400 \mathrm{~km}$ from Afghanistan to India (Arunachal Pradesh-Myanmar border), covering Pakistan, India, Nepal, Bhutan, and Tibet Autonomous Region of China, providing shelter to diverse human cultures, floras, and faunas in its different parts (Das and Bera 2018). Due to a wide range of variations in altitude, aspect, and elements of overall climate, a widely diverse niche of vegetation is developed in its eastern part (E. Nepal to Arunachal Pradesh) and has become one of the essential biodiversity-rich areas in the world. These parts of the Indian Himalayas constitute many particular vegetation types depending upon the diverse combination of climatic and edaphic factors. The area covers the Northeastern states of India, namely, Arunachal Pradesh, Darjeeling part of West Bengal, and Sikkim. In terms of biodiversity, Arunachal Pradesh is the most diverse and most affluent in India, harboring about $50 \%$ of the country's flora, of which 4\% are endemics (Borah et al. 2019).

Arunachal Pradesh hosts as many as 26 major tribes and 110 sub-tribes (Taram et al., 2018). Of them, the Adi, resident of the Siang valley, is one of the numerically more significant tribes comprising $26.9 \%$ of the total tribal population of the state (Krithika et al., 2008). They have several sub-groups, living in different restricted small pockets of the Siang belt and are recognized as Ashing, Bokar, Bori, Karko, Komkar, Milang, Minyong, Simong, Padam, Pangi, and Pasi (Boko and Narsimhan 2015). These sub-groups share similarities in almost every aspect; the only difference is their dialect.

People of the Komkar sub-group reside in a small group of villages at Rasing, Sijer, and Buksang of Komkar-Adi Biocultural Landscape under the Geku Circle in upper Siang District of the state. The major festivals of the Komkar people are Solung, Aran (Unying), and Etor, which are similar to other sub-groups. 'Etor' is celebrated in May, related to community fencing of the village boundaries. A special war dance, 'Taари,' is also performed, re-enacting the action of war, its glory details, and the triumphant cries of the warriors. The headgear worn for dancing is 'leb-ro' made of black fibers from the leaf-sheath of Arenga obtusifolia (Tasat), a white coma of Beaumontia grandiflora dried stem pith of Brassaiopsis glomerular by the Komkar. Other sub-groups use different plant species for this purpose too. Hence, it is linked to the locally available species where a particular group lives long. However, apart from these, their customs remain the same, and all of them have inextricable links to the forest 
resources for their regular sustenance and to meet their day-to-day needs.

Most of the available ethnobotanical publications have recorded primarily qualitative information/data, and such data were not verified through statistical analysis. Recently, many workers have applied quantitative methods in ethnobotany to assess the reliability of the information (Mipun et al., 2019). The concept of quantitative ethnobotany is relatively new, and the term itself was coined only in 1987 by Prance and his co-workers (Prance 1991). The technique is to directly analyze contemporary plants using data and understand how important these plants are to ethnic and indigenous cultures (Phillips and Gentry 1993). Such studies could advance the traditional approach by incorporating appropriate quantitative research methods in ethnobotanical data collection, processing, and interpretation (Hoft et al. 1999; Ong \& Kim 2014; Teklehaymanot and Giday 2010). Quantitative ethnobotanical studies so far have been able to measure the various uses of the plants as food, veterinary medicine, remedies for human disease, and other economic values (Pieroni 2001; Upadhyay et al. 2011; Kim and Song 2013).

The ethnobotanical information is gathered by conducting surveys among the Adi-Komkar community; an appropriate quantitative method is applied to analyze the data that will help understand the importance of such data in the life/society of the people and will assist in framing appropriate strategies to manage the scientific base properly. It also attempts to document the traditional ethnobotanical knowledge of the Komkar people, a subgroup of the Adi community, which, it is expected, will record some new uses of known useful plants or the plants that were not recorded earlier ethnobotanically

\section{MATERIALS AND METHODS}

\section{Study area}

The study was conducted from 2016 to 2019 in Komkar-Adi Biocultural Landscape (three villages Rasing, Sijer, and Buksang) falling under the Geku Circle of Upper Siang District of Arunachal Pradesh. These villages are inhabited by the Komkar sub-group of the Adi tribe. The Adi's are known for their rich traditional knowledge in the whole state, as this tribe is widespread throughout a long belt of this Himalayan state. Each sub-group has adapted to their environment differently, using different plants for their requirements. Hence, it is urgent to document their traditional knowledge to safeguard their tribal heritage. Only three villages were selected because the population of Komkar people is not that high. Even today, they strictly adhere to their traditional cultures and customs, thereby offering the most harmonious society to study their traditional knowledge. The area is bounded east by Simong and Maryang, west by Karko and Pangkang, north by Yingkong, and in the south by Geku and Dite-dime villages.

The central coordinates of Komkar's inhabiting area are $28.464334^{\circ} \mathrm{N}$ and $95.091789^{\circ} \mathrm{E}$ with an elevation of $\mathrm{c}$. $298 \mathrm{~m}$ a.m.s.l. The region enjoys a humid subtropical climate with wet summer and mild winter seasons, and the temperature ranges between $29.5^{\circ} \mathrm{C}$ and $17.7^{\circ} \mathrm{C}$. The average annual rainfall is $2,972.7 \mathrm{~mm}$. The vegetation type of the area is chiefly Subtropical; the dominant trees of the site are Ostodes paniculata, Artocarpus heterophyllus, Rhus chinensis, Toxicodendron hookeri, Pterospermum acerifolium, Castanopsis indica, Erythrina stricta, etc. Adi-Komkar people are primarily dependent on forests for most of their requirements (nutritional, cultural, and medicinal), whereas their primary occupation is agriculture (both humid and wetland cultivation). They mostly follow the old traditional faith and belief system often referred to as 'Donyi Polo.'
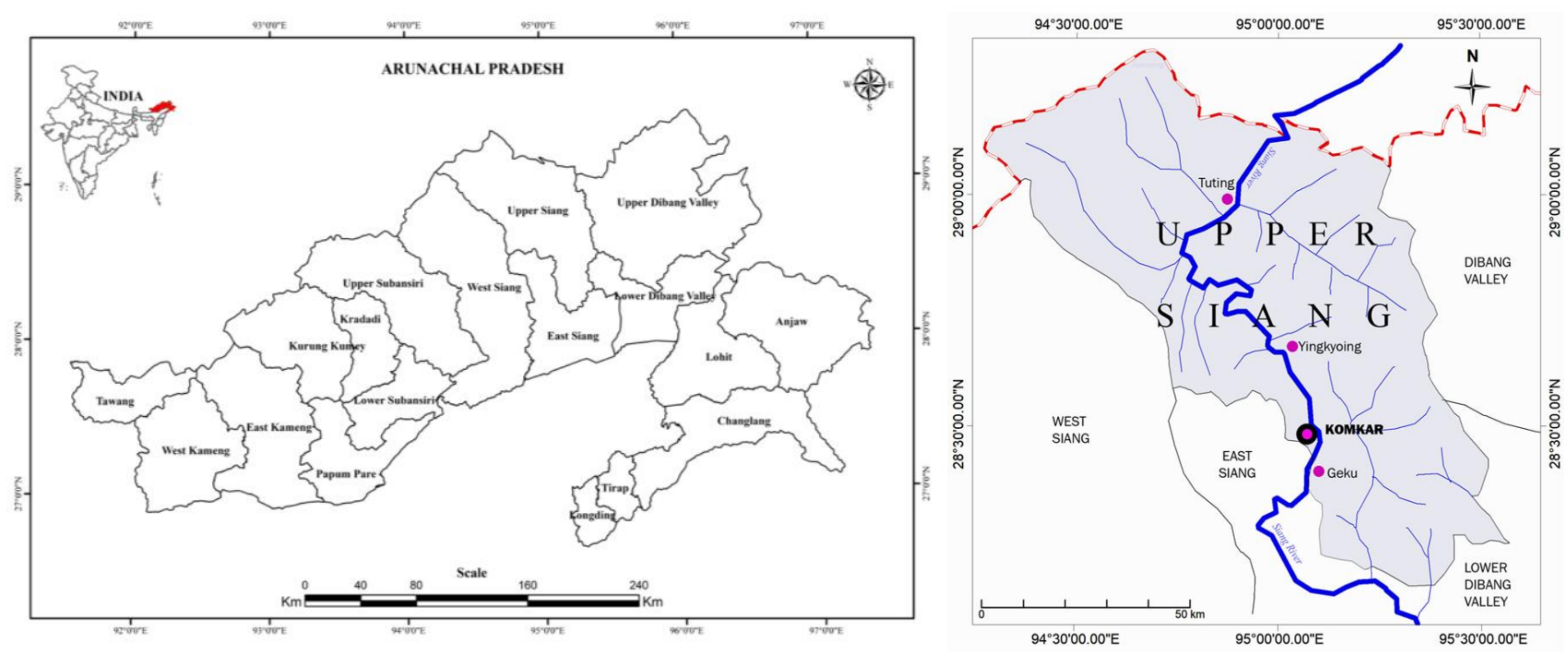

Figure 1. Location of Komkar-Adi Biocultural Landscape, Upper Siang District of Arunachal Pradesh, India 


\section{Data collection}

A total of 41 respondents were interviewed from different households, falling into both the gender and different age-class categories [15-35 years, 35-60 years, and above 60 years]. The respondents were selected on their livelihood pattern and those who frequently access the forests, village heads, traditional healers, and aged people. Data was collected from the sample households through interviews using various participatory rural appraisal tools like semi-structured questionnaires, personal interviews, group discussions, and transect walks with the core respondents for field validation. The mandatory Prior Information Consents (PIC) were taken from the village/ community heads. Voucher specimens were later identified using different literature (Kanjilal et al. 1934-1940; Hooker 1872-1897; Hajra et al. 1996; Giri et al. 2008; Chowdhery et al. 2009) and matched at ARUN and ASSAM Herbaria. The specimens will be deposited in the Herbarium of Arunachal University (HAU), Department of Botany, Rajiv Gandhi University, Rono Hills, Doimukh, Arunachal Pradesh for future references.

\section{Data analysis}

Data collected was analyzed using three quantitative indices following Sharma et al. (2012) and Pardo-desantayana (2003) and are (i) Use value (UV), (ii) Relative Frequency of Citation (RFC), (iii) Relative Importance Index (RI) and (iv) Cultural Importance Index (CI).

$U V$ is calculated using the following formula:

$$
\mathrm{UV}=\mathrm{U} / \mathrm{n}
$$

Where $U$ is the number of use reports cited by every respondent for a given species and $\mathrm{n}$ is the total number of respondents interviewed. The UV is high when there are many valuable reports for a given species, which implies that the taxa are essential. When there are few reports related to its use, the UV decreases.

Relative Frequency of Citation (RFC) is calculated using the following formula:

\section{$\mathrm{RFC}=\mathrm{FCs} / \mathrm{N}$}

Where FC is the Frequency of Citation and $\mathrm{N}$ is the number of informants participating in the survey. This index ranges from 0-1; when the RFC index is 0 , nobody refers to the plant as necessary, and 1 indicates that all informants in the survey refer to the plant as required.

Relative Importance Index (RI) is calculated using the following formula:

$$
\text { Ris }=[R F C s(\max )+R N U s(\max )] / 2
$$

Where RFCs is the relative frequency of citation over the maximum and RNUs is the close number of use categories over the top, viz., it is obtained by dividing the number of uses of the species (NUs) by the maximum value in all the species of the species, [RNUs $(\max )=$ NUs/Max (NU)]. The value ranges from 0-1; when the RI index is 0 , nobody mentions any use of the value. When the $\mathrm{RI}$ index is 1 , the plant was the most frequently mentioned as useful in the maximum number of use categories.

Cultural Importance Index (CI) is calculated using the following formula:

$$
C I s=\sum_{u=u i}^{U_{N C}} \sum_{i=i l}^{i N} U R_{U i / N}
$$

For example, in the case of Artemisia indica, 25 informants out of 50 reported this species as useful in the general category, and there is no other use category. Hence, $\mathrm{CI}_{\text {A. indica }}=25 / 50=0.5$

\section{RESULTS AND DISCUSSION}

\section{Results}

A total of 301 taxa falling in 203 genera and 85 families are used by the people of Komkar-Adi Biocultural Landscape (Table S1). Of which $93.36 \%$ (281) are angiosperms, pteridophytes $3.98 \%$ (12) and Fungi 2.66\% (8). 235 taxa were native to the region, whereas 57 are exotics (POWO 2019).

Among the plant-parts used, fruits showed the highest frequency of uses $(23.75 \%)$, followed by leaves $(19.35 \%)$, tender shoots $(11.43 \%)$, whole plants $(7.91 \%)$, seeds $(6.15$ $\%)$, flowers $(3.51 \%)$, rhizome $(3.22 \%)$, fronds $(2.93 \%)$, stem $(2.93 \%)$, sporocarp $(2.34 \%)$, bark $(2.05 \%)$, culms $(1.75 \%)$, inflorescence $(1.46 \%)$, petiole $(1.46 \%)$, rootstocks $(1.46 \%)$, twigs $(1.46 \%)$, stem pith $(1.17 \%)$, tubers $(1.17 \%)$, endosperm $(0.87 \%)$, mid veins $(0.87 \%)$, corms $(0.58 \%)$, bulbils $(0.29 \%)$, calyx $(0.29 \%)$, leaf sheath $(0.29 \%)$, lignotuber $(0.29 \%)$, resin $(0.29 \%)$, roots $(0.29 \%)$ and sap $(0.29 \%)$.

Dividing into use categories, it was found that the majority of the plants fall under food $(54.13 \%)$ followed by medicine (15.94\%), rituals beliefs and customs (11.11\%), household materials $(4.84 \%)$, fishing $(2.56 \%)$, hunting $(2.56 \%)$, masticatory $(2.56 \%)$, construction $(2.27 \%)$, fodder $(1.7 \%)$ and fencing $(0.85 \%)$.

Considering the habit groups, the tree was the most dominant with 72 spp. (23.92\%), followed by annual herbs (58 spp., 19.26\%), shrubs (45 taxa, 14.95\%), perennial herb (40 spp., 13.28\%), Geophytic herbs (17 spp., 5.64\%), a shrubby climber (12 spp., 3.98\%), liana (11 spp., 3.65\%), an herbaceous climber (10 spp., 3.32\%), fungal fruit body (8 spp., 2.65\%), bamboo (7 spp., 2.32\%), epiphytes (7 spp., $2.32 \%$ ), suffrutescents (5 spp., 1.66\%), palm (4 spp., $1.32 \%$ ), geophytic climbers (3 spp., $0.99 \%$ ), root parasite and stem parasite with one species each $(0.33 \%)$. The surrounding vegetation was forest-dominated, which might have provided facilities to test more tree species. However, in open areas, along the forest margins, besides marshlands, around the settlements, etc., herbaceous plants are dominant, so, are coming easily into view and contact people and are mostly used.

Use value (UV) of all the reported species ranges between 0.017 and 0.051 (Table S1). The plants with the highest UV indicate species considered most important by 
the Adi people for their repeated treatment use. And those species are conserved locally by following cultivation practices in their respective home gardens and community lands due to their high harvesting pressure. A total of 48 ethnomedicinal plant species, including herbs, shrubs, and trees, are used to cure 35 different ailments. Solanum spirale is considered the most important as it predominates in the landscape and is mentioned by a higher number of informants $(\mathrm{FC}=52)$. Table 1 shows a comparison between three different indices CI, RFC, and RI, indicating species ranking based on each index and the three fundamental values of the study, viz. FC, UR, and NU for each species.

Table 1. Evaluation of plant species used in medicinal practices of the analyzed areas using CI, RFC, and RI quantitative indices

\begin{tabular}{|c|c|c|c|c|c|c|}
\hline \multirow{2}{*}{ Botanical name } & \multicolumn{3}{|c|}{ Basic values } & \multicolumn{3}{|c|}{ Indices } \\
\hline & FC & UR & $\mathbf{N U}$ & CI & RFC & RI \\
\hline Agapetes macrantha var. grandiflora & 15 & 15 & 1 & 0.26 & 0.26 & 0.27 \\
\hline Ageratum conyzoides & 30 & 50 & 3 & 0.86 & 0.52 & 0.66 \\
\hline Ageratum houstonianum & 15 & 22 & 2 & 0.38 & 0.26 & 0.39 \\
\hline Arenga obtusifolia & 16 & 25 & 2 & 0.43 & 0.28 & 0.40 \\
\hline Artemesia indica & 23 & 30 & 2 & 0.52 & 0.40 & 0.47 \\
\hline Bambusa tulda & 33 & 48 & 4 & 0.83 & 0.57 & 0.82 \\
\hline Begonia aborensis & 17 & 31 & 2 & 0.53 & 0.29 & 0.41 \\
\hline Begonia griffithiana & 17 & 27 & 2 & 0.47 & 0.29 & 0.41 \\
\hline Begonia silletensis & 36 & 55 & 2 & 0.95 & 0.62 & 0.60 \\
\hline Blumea balsimifera & 28 & 32 & 2 & 0.55 & 0.48 & 0.52 \\
\hline Brachystemma calycinum & 22 & 22 & 1 & 0.38 & 0.38 & 0.34 \\
\hline Bryophyllum pinnatum & 25 & 40 & 2 & 0.69 & 0.43 & 0.49 \\
\hline Centella Asiatica & 32 & 51 & 3 & 0.88 & 0.55 & 0.68 \\
\hline Chromolaena odorata & 22 & 30 & 2 & 0.51 & 0.37 & 0.46 \\
\hline Clerodendron colebrookeanum & 51 & 55 & 2 & 0.95 & 0.88 & 0.74 \\
\hline Curcuma caesia & 20 & 33 & 2 & 0.57 & 0.34 & 0.44 \\
\hline Curcuma longa & 45 & 55 & 2 & 0.95 & 0.78 & 0.68 \\
\hline Cyclosorus parasiticus & 25 & 25 & 1 & 0.43 & 0.43 & 0.37 \\
\hline Dendrocalamus hamiltonii & 36 & 52 & 3 & 0.90 & 0.62 & 0.72 \\
\hline Dendrocnide sinuata & 37 & 51 & 2 & 0.88 & 0.64 & 0.61 \\
\hline Euphorbia royleana & 34 & 49 & 2 & 0.84 & 0.59 & 0.58 \\
\hline Garcinia pedunculata & 32 & 49 & 2 & 0.84 & 0.55 & 0.56 \\
\hline Hedyotis scandens & 30 & 47 & 2 & 0.81 & 0.52 & 0.54 \\
\hline Houttuynia cordata & 41 & 55 & 3 & 0.95 & 0.71 & 0.77 \\
\hline Kaempferia galanga & 18 & 18 & 1 & 0.31 & 0.31 & 0.30 \\
\hline Melotheria heterophylla & 28 & 45 & 3 & 0.78 & 0.48 & 0.64 \\
\hline Mikania micrantha & 19 & 33 & 2 & 0.57 & 0.33 & 0.43 \\
\hline Morus macroura & 22 & 30 & 2 & 0.52 & 0.38 & 0.46 \\
\hline Neprolepsis cordifolia & 17 & 17 & 1 & 0.29 & 0.29 & 0.29 \\
\hline Nicotiana tabacum & 40 & 45 & 2 & 0.78 & 0.69 & 0.63 \\
\hline Oryza sativa & 26 & 37 & 2 & 0.64 & 0.45 & 0.50 \\
\hline Oxalis corniculata & 20 & 20 & 1 & 0.34 & 0.34 & 0.32 \\
\hline Paederia foetida & 36 & 54 & 2 & 0.93 & 0.62 & 0.60 \\
\hline Paris polyphylla & 50 & 55 & 3 & 0.95 & 0.86 & 0.86 \\
\hline Photos scandens & 31 & 33 & 2 & 0.57 & 0.53 & 0.55 \\
\hline Phrynium pubinerve & 27 & 38 & 2 & 0.66 & 0.47 & 0.51 \\
\hline Psidium guajava & 19 & 27 & 2 & 0.47 & 0.33 & 0.43 \\
\hline Pueraria Montana & 13 & 21 & 2 & 0.36 & 0.22 & 0.38 \\
\hline Rhus chinensis & 49 & 50 & 2 & 0.86 & 0.84 & 0.72 \\
\hline Ricinus communis & 40 & 53 & 3 & 0.91 & 0.69 & 0.76 \\
\hline Setaria italica & 10 & 16 & 2 & 0.28 & 0.17 & 0.35 \\
\hline Solanum spirale & 52 & 53 & 2 & 0.91 & 0.90 & 0.75 \\
\hline Solanum viarum & 35 & 52 & 2 & 0.90 & 0.60 & 0.59 \\
\hline Solanum violaceum & 39 & 43 & 2 & 0.74 & 0.67 & 0.63 \\
\hline Urtica dioica & 49 & 57 & 4 & 0.98 & 0.84 & 0.97 \\
\hline Urtica parviflora & 15 & 15 & 1 & 0.26 & 0.26 & 0.27 \\
\hline Zanthoxylum armatum & 36 & 46 & 2 & 0.79 & 0.62 & 0.60 \\
\hline Zingiber officinale & 29 & 39 & 2 & 0.67 & 0.50 & 0.53 \\
\hline Zingiber sianginensis & 28 & 35 & 3 & 0.60 & 0.48 & 0.64 \\
\hline
\end{tabular}


According to the CI index, Urtica dioica is the most culturally significant, with a value of 0.98. Along with 49 citations (FC) and 57 use reports (UR). It is followed by Paris polyphylla with the $\mathrm{CI}$ of $0.94(\mathrm{FC}=50$ and $\mathrm{UR}=55)$, Houttuynia cordata $(\mathrm{CI}=0.94, \quad \mathrm{FC}=51$ and $\mathrm{UR}=55)$, Curcuma longa $(\mathrm{CI}=0.94, \quad \mathrm{FC}=45$ and $\mathrm{UR}=55)$, Clerodendrum colebrookeanum $(\mathrm{CI}=0.94, \quad \mathrm{FC}=51$ and $\mathrm{UR}=55)$ and Begonia silletensis $(\mathrm{CI}=0.94, \mathrm{FC}=36$ and $\mathrm{UR}=55)$. The highest RI value (0.97) of Urtica dioica signifies greater importance to its multiple uses, and the species was mentioned in a higher number of use categories $(\mathrm{NU}=4)$. The result found that Urtica dioica, Solanum spirale, Paris polyphylla, Curcuma longa, Clerodendrum colebrookeanum, and Begonia silletensis are largely used by the community in the treatment of human and animal diseases.

\section{Discussion}

The plants reported in this study is far more than the earlier studies conducted on the Adi tribe, residing in different regions of the Arunachal Pradesh by Tag et al. (2008); Srivastava and Adi community (2009); Yumnam et al. (2011); Boko et al. (2014); Kumar et al. (2015); Murtem and Chaudhry (2016); Bhuyan et al. (2017); Ayam et al. (2017); Jeyaprakash et al. (2017).

The dependence of these people on ethnobotanical resources may be due to their well-known health benefits or feeling the mere pleasure of gathering, recreation, and enjoying exquisite natural flavors (Pardo-de-Santayana et al., 2007). Their vast traditional knowledge of wild edible plants used by the community is time-tested, eco-friendly, and supportive of livelihood. Traditional knowledge of their ancestors regarding the food habits and the location of their settlements in biodiversity-rich remote Himalayan corners always provided natural resources for their survival. Also, the scarcity of cultivable land forced them to lead a lifestyle where they partially practiced agriculture and depended on available bioresources in their surroundings. It has been observed that among the 301 plants, more than half were used as different types. Some plants are commonly consumed by every household and have one or more types of uses, such as Asystasiella neesiana, Deeringia amaranthoides, Dioscorea alata, Fagopyrum esculentum, Piper pedicellatum, Zanthoxylum oxyphyllum, Clerodendrum glandulosam, Arenga obtusifolia, Calamus Erectus, and Houttuynia cordata. These essential plants represent the core of wild food plants for the people of Komkar-Adi Biocultural Landscape. This is because of the frequent distribution and easy availability in the region. The use of such fantastic resources for providing additional needs has also paved its way into the semi-domestication of some plants in their backyards and kitchen gardens. It includes Fagopyrum esculentum, Piper pedicellatum, Clerodendrum colebrookeanum, Asystasiella neesiana, Deeringia amaranthoides, Arenga obtusifolia, and Houttuynia cordata.

Ethno-medicines also play a vital role in the rugged terrains, where advanced medical facilities are not yet to be available. Their ethnomedicinal knowledge speaks of their medical history and common ailments. In the present study,
$32 \%$ of the medicinal plants are reported to treat gastrointestinal disorders, nearly one-fourth of the total plants used by the whole of the Adi tribe (Kagyung et al., 2010). A total of 31 plant species has been recorded to treat a variety of disorders which is higher than the plants used by the Minyong sub-tribe as reported by Baruah et al. (2013) and far more than the total species recorded by Danggen et al. (2018), Gibji et al. (2012) for the Adi tribe of Eastern Himalaya. This study also recorded 9 species of ethnoveterinary knowledge used by the local healers.

A comparison with all the available literature related to the ethnobotanical resources of the Adi tribe (Mibang et al. 2003, Singh et al. 2007a, Singh et al. 2007b, Rethy et al. 2010, Khongsai et al. 2011, Nimasow et al. 2012, Payum et al. 2014, Chetry et al. 2018, Nanda et al. 2018) revealed that 19 plants (Agapetes macrantha var. Grandiflora, Arenga obtusifolia, Begonia aborensis, Begonia acetosella, Begonia silletensis, Blumea balsamifera, Brachystemma calycinum, Dendrocnide sinuata, Kaempferia galanga, Morus macroura, Nephrolepis cordifolia, Oryza sativa, Phrynium pubinerve, Rhus Chinensis, Setaria italica, Solanum violaceum, Solena heterophylla, Urtica ardens, and Urtica dioica) are a new record for ethnomedicinal uses by the tribe. Four species (Ageratum conyzoides, Ageratum houstonianum, Bryophyllum pinnatum, and Solanum spirale) are new records for medicinal uses against different ailments. Another two species (Euphorbia royleana and Nicotiana tabacum) are reported as new for ethnoveterinary user benefits. Calculating the quantitative indices found Urtica dioica, Solanum spirale, Paris polyphylla, Curcuma longa, Clerodendrum colebrookeanum, and Begonia silletensis are the most important plant species used by the Komkar Adi in the treatment of various ailments. More work needs to be done on those particular plants with higher values to validate their traditional medicinal uses and check their bioactive constituents for further drug development. This type of study could open a new path for future pharmacological research, serving as a reference for dealing with the rich ethnobotanical knowledge of diverse ethnolinguistic indigenous groups.

It is also observed that exotic elements such as Bidens pilosa, Chromolaena odorata, Ageratum conyzoides, Nasturtium microphyllum, Erigeron Canadensis, etc. have gradually entered into the traditional knowledge livelihood system of the Komkar-Adi, as food and medicine.

Hunting and fishing have played a vital role in the lifestyle of tribal people. Apart from their protein needs, it has always been a favorite pastime for youths. Since time memorial, they have been using innovative techniques and traps. A total of 18 plants is recorded here used in their traditional ways of fishing and hunting, either as baits, as poison, adhesive, etc., which is half the number of species reported by Yumnam and Tripathi (2013) for the entire Adi community.

Some plants or groups are sometimes given particular importance due to their long history of extensive use. Bamboos are part and parcel of the life of Adi people and are used in innumerable ways. Sharma and Borthakur (2008) reported different benefits of 15 species of bamboos by the whole Adi community, twice the number ( $8 \mathrm{spp}$.) 
reported in the present study. Similarly, for the wild or local species of Allium, as many as 9 species are known to occur in the region (Devi et al. 2014), and the Adi-Komkar community is using only 2 of them.

Traditional knowledge also became important in their art of living. Different phenophases of some plants are found to use as biological indicators. For example, flowering and fruiting of many plants embark seasons, acting as biological indicators. The Adi people are primarily agricultural. Capparis multiflora and Melastoma malabathricum blooms in April, and that flag-off the time to broadcast paddy seeds. Similarly, the blooming of Erythrina stricta indicates the time for cultivating different types of beans in the region. The shift in the phenology of such plants primarily due to climatic imbalance causes damage to their livelihood crops.

The Adi people are primarily followers of Donyi-Polo (the Sun and Moon), where they keep faith in Nature like God. Hence, Nature and its associated myths play a vital part in their rural lifestyle. Since time immemorial, the Komkar-Adi have lived in complete harmony with plants while harvesting their daily minimum requirements from the forest for their survival. The example of the erection of gates along the village boundary with the long and spreading fronds of Cyathea gigantea for controlling the spread of infectious diseases is one such example. They firmly believe that the tree fern possesses divine power that ensures the community's security, health, and prosperity. Such plants are not frequently harvested except for ritual purposes. This idea underlies the conservation ethics of the communities associated with many plant species, including the tree-ferns, due to their close association with nature.

\section{ACKNOWLEDGEMENTS}

The authors are thankful to Rajiv Gandhi University for providing the necessary facilities. They are also grateful to the local traditional knowledge holders of the community for sharing their valuable knowledge system. Invaluable help rendered by Omeng Minno, Ojar Taku, and Bosong Taram during the field survey, Hui Tag for his helpful comments, and Jambey Tsering for the map is sincerely acknowledged and appreciated.

\section{REFERENCES}

Ayam VS, Nyitan J. 2017. Plants that Influences the Socio-cultural of Adis of Arunachal Pradesh. Intl J Res 5: 16-19. DOI: 10.20431/2349. 0365.0506004

Baruah S, Borthakur SK, Gogoi P, Ahmed M. 2013. Ethnomedicinal plants used by Adi-Minyong tribe of Arunachal Pradesh, eastern Himalayas. Indian J Nat Prod Res 4: 278-282.

Bhuyan LR, Pangu Y, Tam N. 2017. Ethnobotanical studies on Khamba and Adi tribes of Tuting area, Upper Siang District, Arunachal Pradesh. Bull Arunachal For Res 32: 27-40.

Boko N, Narsimhan D. 2014. Rapid survey of plants used by Adi tribe of Bosing Banggo, East Siang District, Arunachal Pradesh, India. Pleione 8: 271-282.

Boko N, Narsimhan D. 2015. House of Adi Tribe of Arunachal Pradesh Construction materials and the use of space. Intl J Innov Res Adv Stud 2: 1-6.
Borah D, Das AP, Tangjang S, Wangpan T. 2019. Flowering Plant Diversity in the Alpine Regions of Eastern Himalaya. In Jayanta Kumar Patra, Gitishree Das, Sanjeet Kumar, Hrudayanath Thatoi (eds.) Ethnopharmacology and Biodiversity of Medicinal Plants. Apple Academic Press, Palm Bay, Florida, USA. DOI: 10.1201/9780429398193-8.

Chetry LB, Bharali MK, Basar K, Taye K, Taka T, Tsering J, Wangpan T. 2018. Medicinal Plants used against gastrointestinal disorders among the Adi Tribe of Eastern Himalaya. NeBIO 9: 93-10.

Chowdhery HJ, Giri GS, Pramanik A. 2009. Materials for the Flora of Arunachal Pradesh. Vol. III. Botanical Survey of India, Calcutta.

Danggen O, Mello J, Ering K, Hussain A, Saikia V. 2018. Ethnomedicinal Plant Knowledge among the Adi Tribe of Yingkiong and Mariyang Valley, Upper Siang District, Arunachal Pradesh, India. Intl J Pure Appl Biosci 6: 1504-1511. DOI: 10.18782/2320-7051.5432.

Das AP, Bera S. 2018. Preface. In: Das AP, Bera S. (eds.), Plant Diversity in the Himalaya Hotspot Region 1. Bishen Singh Mahendra Pal Singh, Dehradun.

Devi A, Rakhsit K, Sarania B, Adi, Apatani, Monpa, Nyishi Community. 2014. Ethnobotanical notes on Allium species of Arunachal Pradesh, India. Indian J Trad Knowl 13: 606-612.

Gibji N, Ringu N, Dai NO. 2012. Ethnomedicinal knowledge among the Adi tribes of Lower Dibang Valley District of Arunachal Pradesh, India. Intl Res J Pharm 3: 223-229.

Giri GS, Pramanik A, Chowdhery HJ. 2008. Materials for the Flora of Arunachal Pradesh. Vol. II. Botanical Survey of India, Kolkata.

Hajra PK, Verma DM, Giri GS. 1996. Materials for the Flora of Arunachal Pradesh. Vol. I. Botanical Survey of India, Calcutta.

Höft M, Barik SK, Lykke AM. 1999. Quantitative ethnobotany: Applications of multivariate and statistical analyses in ethnobotany. People and Plants Working Paper 6, UNESCO, Paris.

Hooker JD. 1872-1897. The Flora of British India I-VII L. Reeve and Company, London

Jeyaprakash K, Lego YJ, Payum T, Rathinavel S, Jayakumar K. 2017. Diversity of Medicinal Plants used by Adi Community in and around the area of D' Ering Wildlife Sanctuary, Arunachal Pradesh, India. World Sci News 65: 135-159.

Kagyung R, Gajurel PR, Rethy P, Singh B. 2010. Ethnomedicinal plants used for gastrointestinal diseases by Adi tribes of Dehang-Debang Biosphere Reserve in Arunachal Pradesh. Indian J Trad Knowl 9: 496-501.

Kanjilal UN, Das A, Kanjilal PC, Purkayastha C, Dey RN, Bor NL. 19341940. Flora of Assam 1-5. Government of Assam, Shillong.

Khongsai M, Saikia SP, Kayang H. 2011. Ethno-medicinal plants used by different tribes of Arunachal Pradesh. Indian J Trad Knowl 10: 541546.

Kim H, Song MJ. 2013. Ethnomedicinal practices for treating liver disorders of local communities in the southern regions of Korea. Evidence-Based Complementary Alternative Medicine: 2013: 869176. DOI: $10.1155 / 2013 / 869176$.

Krithika S, Maji, Vasulu TS. 2008. A microsatellite guided insight into the genetic status of Adi, an isolated hunting-gathering tribe of Northeast India. PLoS One 3: e2549. 10.1371/journal.pone.0002549.

Kumar N, Kumar S, Singh B, Mishra BP, Singh B, Singh V. 2015. Traditional practices of utilization and conservation of non-wood forest products by Adi tribes of Arunachal Pradesh. J Appl Nat Sci 7: 111-118. DOI: 10.31018/jans.v7i1.573.

Mibang T, Choudhuri SK. 2003. Ethnomedicines of the tribes of Arunachal Pradesh. Himalayan Publishers, New Delhi (India).

Mipun P, Bhat NA, Borah D, Kumar Y. 2019. Non-timber forest products and their contribution to healthcare and livelihood security among the Karbi tribe in Northeast India. Ecological Processes 8: 41. DOI: 10.1186/s13717-019-194-4.

Murtem G, Chaudhry P. 2016. An ethnobotanical study of medicinal plants used by the tribes in Upper Subansiri District of Arunachal Pradesh, India. Ameri J Ethnomed 3: 35-49.

Nanda P, Teyi C, Gocham Y, Kumji T, Sharma H, Muthu J. 2018. Indigenous methods of preparation of tassey from palm tree Arenga obtusifolia Griff. by the Nyishi tribe of Kurung Kumey, Arunachal Pradesh, India. Intl Res J Biol Sci 7: 62-65.

Nimasow G, Ringu N, Nimasow OD. 2012. Ethnomedicinal Knowledge among the Adi Tribes of Lower Dibang Valley, Arunachal Pradesh, India. Intl Res J Pharm 3: 223-229.

Ong GH, Kim DY. 2014. Quantitative ethnobotanical study of the medicinal plants used by the Ati Negrito indigenous group in 
Guimaras Island, Philippines. J Ethnopharmacol 157: 228-242. DOI: 10.1016/j.jep.2014.09.015

Pardo-de-Santayana M, Blanco JTE, Carvalho AM, Lastra JJ, Miguel ES Morales R. 2007. Traditional knowledge of wild edible plants used in the northwest of the Iberian Peninsula (Spain and Portugal): a comparative study. J Ethnobiol Ethnomed 3: 27. DOI: 10.1186/17464269-3-27

Payum T, Das AK, Shankar R. 2014. Nutraceutical folk food plants used among indigenous people of East Siang District of Arunachal Pradesh, India. Amer J PharmTech Res 4: 696-704.

Phillips OLB, Gentry AH. 1993. The useful plants of Tambopata, Peru. II additional hypothesis testing in quantitative ethnobotany. Econ Bot 47: 32-43. DOI: $10.1007 / \mathrm{BF} 02862204$.

Pieroni A. 2001. Evaluation of the cultural significance of wild food botanicals traditionally consumed in Northwestern Tuscany, Italy. J Ethnobiol 21: 89-104.

POWO. 2019. Plants of the World Online. Facilitated by the Royal Botanic Gardens, Kew. Published on the Internet; http: //www.plantsoftheworldonline.org/ Retrieved 21 January 2020.

Prance GT. 1991. What is ethnobotany today?. J Ethnopharmacol 32: 209 216. DOI: 10.1016/0378-8741(91)90120-3.

Rethy P, Singh B, Kagyung R, Gajurel PR. 2010. Ethnobotanical studies of Dehang Debang Biosphere reserve of Arunachal Pradesh with special reference to Memba tribe. Indian J Trad Knowl 9: 61-67.

Sharma TP, Borthakur SK. 2008. Ethnobotanical observations on Bamboos among Adi tribes in Arunachal Pradesh. Indian J Trad Know1 7: 594-597. DOI: 10.1016/j.jep.2012.06.053

Sharma UK, Pegu S, Hazarika D, Das A. 2012. Medico-religious plants used by the Hajong community of Assam, India. J Ethnopharmacol 143: 787-800.
Singh RK, Singh A, Tag H. 2007. Traditional skill among Adi tribes of Arunachal Pradesh. Indian J Trad Knowl 7: 27-36.

Singh RK, Sureja AK, Turner NJ. 2007. Food and cultural values of hidden harvest in livelihood of Adi tribes of Arunachal Pradesh. Indian J Ext Educat 43: 56-62.

Srivastava RC, Adi community. 2009. Traditional knowledge of Adi tribe of Arunachal Pradesh on plants. Indian J Trad Knowl 8: 146-153.

Tag H, Murtem G, Das AK, Singh RK. 2008. Diversity distribution of ethnobotanical plants used by Adi tribe of East Siang District of Arunachal Pradesh, India. Pleione 2: 123-136.

Taram M, Borah D, Rinyo R, Tag H. 2018. Wild Food Plant Resources of Komkar Adi Tribe of Upper Siang District in Arunachal Pradesh, India. Bulletin of Arunachal Forest Res 33: 27-35.

Teklehaymanot T, Giday M. 2010. Quantitative ethnobotany of medicinal plants used by Kara and Kwego semi-pastoralist people in lower Omo River Valley, Debub Omo Zone, Southern Nations, Nationalities and Peoples Regional State, Ethiopia. J Ethnopharmacol 130: 76-84. DOI: 10.1016/j.jep.2010.04.013.

Upadhyay B, Singh KP, Kumar A. 2011. Ethnoveterinary uses and informants consensus factor of medicinal plants of Sariska region, Rajasthan, India. J Ethnopharmacol 133: 14-25. DOI: 10.1016/j.jep.2010.08.054.

Yumnam JY, Bhuyan SI, Tripathi OP, Khan ML. 2011. Study on the ethnomedicinal plants used by Adi tribe of East Siang District, Arunachal Pradesh. J Econ Taxon Bot 35: 369-377.

Yumnam JY, Tripathi OP. 2013. Ethnobotany: Plants use in fishing \& hunting by Adi tribe of Arunachal Pradesh. Indian J Trad Knowl 12: 157-161. 
Table S1. List of ethnobotanicals used by the Adi-Komkar tribe in Arunachal Pradesh, India

[Abbreviations used: Habit: B: Bamboo; HA: Annual Herb; HG: Geophytic Herb; HP: Perennial Herb; CG: Geophytic Climber; CH: Herbaceous Climber; CS: Shrubby Climber; E: Epiphyte; FB: Fungal fruit-body; L: Liana; P: Palm; PR: Root Parasite; PS: Stem Parasite; Sf: Suffrutescent; S: Shrub; T: Tree. Uses F: Food; M: Medicine; H: Hunting; Fh: Fishing; RBC: Rituals, beliefs, and Customs; O: Others; C: Construction; HHM: House Hold Materials; Fd: Fodder; Mst: Masticatory; Fn: Fence.Plant Parts used: Br: Bark; Bu: Bulbil; Cm: Culm; Cr: Corm; Cy: Calyx; En: Endosperm; Fl: Flower; Fn: Frond; Fr: Fruit; In: Inflorescence; Lf: Leaf; Lsp: Leaf-sheath powder; Lt: Lignotuber; Lx: Latex; Pt: Petiole; Re: Resin; Rh: Rhizome; Rs: Tuberous Root Stock; Rt: Root; Sa: Sap; Sd: Seed; Sp: Stem pith; St: Stem; Ts: Tender Shoot; Tu: Tuber; Tw: Twig; Vn: Vein;.Wh: Whole plant. Distribution: E: Exotic; N: Native;-: not known.]

\begin{tabular}{|c|c|c|c|c|c|c|}
\hline Botanical name [Family]; Voucher specimen & $\begin{array}{l}\text { Adi-Komkar } \\
\text { name }\end{array}$ & Habit & Part used & Used and application & $\begin{array}{c}\text { Distribu } \\
\text { tion }\end{array}$ & $\begin{array}{c}\text { Use value } \\
\text { (UV) }\end{array}$ \\
\hline Acacia rugata (Lam.) Fawc. \& Rendle [Fabaceae]; MT-1501 & Ramgir taang & $\mathrm{L}$ & $\mathrm{Br}$ & Fh: Paste mixed in water to stupefy fishes & $\mathrm{N}$ & 0.017 \\
\hline Acmella oleracea (L.) R.K. Jansen[Asteraceae]; MT-1507 & Marshang & HA & Ts & F: Cooked as a vegetable & E & 0.017 \\
\hline Acmella paniculata (Wall.ex DC.) R.K. Jansen [Asteraceae]; MT-1528 & Marshang-haali & HA & Lf & F: Cooked as a vegetable & $\mathrm{E}$ & 0.017 \\
\hline Aconitum feroxWall. ex Ser. [Ranunculaceae]; MT-1506 & Eemo & HP & $\mathrm{Rh}$ & H: Poisoning arrowheads for hunting & $\mathrm{N}$ & 0.017 \\
\hline Actephila excelsa (Dalzell) Mull.Arg [Phyllanthaceae]; MT-1508 & Kamtar-oying & $\mathrm{S}$ & Ts & F: Cooked as a vegetable & $\mathrm{N}$ & 0.017 \\
\hline Aeschynanthus parasiticus C.B. Clarke [Gesneriaceae]; MT- 1503 & Epom marsi & $\mathrm{E}$ & $\mathrm{Fl}$ & RBC: believed to be of Jungle spirit's property & $\mathrm{N}$ & 0.017 \\
\hline Aeschynanthus micranthus C.B. Clarke [Gesneriaceae]; MT-1504 & Epom marsi & E & $\mathrm{Fl}$ & RBC: believed to be of Jungle spirit's property & $\mathrm{N}$ & 0.017 \\
\hline Aeschynanthus monetarius Dunn [Gesneriaceae]; MT-1811 & Epom marsi & $\mathrm{E}$ & $\mathrm{Fl}$ & RBC: It is believed to be of Jungle spirits property & $\mathrm{N}$ & 0.017 \\
\hline $\begin{array}{l}\text { Aeschynanthus novogracilis W.T.Wang } \\
\text { [A. gracilis C.S.P.Paris ex C.B Clarke] [Gesneriaceae]; MT-1505 }\end{array}$ & Epom marsi & $\mathrm{E}$ & $\mathrm{Fl}$ & $\begin{array}{l}\text { RBC: believed to be Jungle spirit's property [spirit's use } \\
\text { red flowers as their chili.'Epom" means jungle spirit; } \\
\text { "Marsi" means chili] }\end{array}$ & $\mathrm{N}$ & 0.017 \\
\hline $\begin{array}{l}\text { Agapetes macrantha var. grandiflora (Hook.f.) D.Banik \& Sanjappa } \\
\text { [Ericaceae]; } M T-1502\end{array}$ & Asi ponying & $\mathrm{CS}$ & $\mathrm{Fl}, \mathrm{Lt}$ & $\begin{array}{l}\text { F: Flowers edible; M: Paste of lignotuber given topically to } \\
\text { treat snake bite }\end{array}$ & $\mathrm{N}$ & 0.034 \\
\hline Ageratum conyzoides $($ L.) L. [Asteraceae]; MT-1509 & $\begin{array}{l}\text { Namsing eeing/ } \\
\text { Migom Dumpu }\end{array}$ & HA & $\mathrm{Lf}$ & $\begin{array}{l}\text { M: Paste applied topically for cuts and wounds; juice gave } \\
\text { orally in malaria }\end{array}$ & $\mathrm{E}$ & 0.017 \\
\hline Ageratum houstonianum Mill. [Asteraceae]; MT-1734 & $\begin{array}{l}\text { Namsing eeing/ } \\
\text { Migom Dumpu }\end{array}$ & HA & $\mathrm{Lf}$ & Paste applied topically on cuts and wounds to clot blood & $\mathrm{E}$ & 0.017 \\
\hline Albizia odoratissima (L.f.) Benth. [Fabaceae]; MT-1550 & Tatkung & $\mathrm{T}$ & St & $\begin{array}{l}\text { C: Trunk to make mortar for traditional paddy de-husking } \\
\text { (Kii-par) }\end{array}$ & $\mathrm{N}$ & 0.017 \\
\hline Allium chinense G.Don [Amaryllidaceae]; MT-1573 & Talab/dilab & HA & $\mathrm{Wh}$ & $\begin{array}{l}\text { F: Whole plants edible; RBC: crushed bulb applied on } \\
\text { body as protection from snakes and wandering soul }\end{array}$ & $\mathrm{E}$ & 0.034 \\
\hline Allium hookeri Thwaites [Amaryllidaceae]; MT-1634 & $\begin{array}{l}\text { Disa talab/ } \\
\text { byakung }\end{array}$ & $\mathrm{HP}$ & Lf, Rt & $\begin{array}{l}\text { F: Leaves edible; RBC: roots taken as a necklace during a } \\
\text { local festival, believes that will protect them from } \\
\text { infectious diseases }\end{array}$ & $\mathrm{N}$ & 0.034 \\
\hline Alocasia macrorrhizos (L.) G.Don [Araceae]; MT-1605 & Ruksin & HP & $\mathrm{Wh}$ & Fd: Cooked with paddy husk for pigs & $\mathrm{E}$ & 0.017 \\
\hline Alpinia nigra (Gaertn.) Burtt [Zingiberaceae]; MT3110 & Gumba-bera & HG & Fr & F: Ripe ones eaten raw & $\mathrm{N}$ & 0.017 \\
\hline Alpinia roxburghii Sweet [Zingiberaceae]; MT-1683 & Gumba-bera & HG & $\mathrm{Fr}$ & F: Ripe ones eaten raw & $\mathrm{N}$ & 0.017 \\
\hline Altingia excelsa Noronha [Altingiaceae]; MT-1692 & Hiri/siri & $\mathrm{T}$ & $\mathrm{Tw}$ & $\begin{array}{l}\text { RBC: With belief, twigs are tied to pillars to strengthen the } \\
\text { roof }\end{array}$ & $\mathrm{N}$ & 0.017 \\
\hline Amaranthus spinosus L. [Amaranthaceae]; MT-1565 & Tapi-pilee & HA & Ts & F: Cooked as a vegetable & $\mathrm{E}$ & 0.017 \\
\hline Amaranthus viridis L. [Amaranthaceae]; MT-1564 & Tapi-pilee & HA & Ts & F: Cooked as a vegetable & $\mathrm{N}$ & 0.017 \\
\hline
\end{tabular}


Amomum pterocarpum Thwaites [Zingiberaceae]; MT-1578

Amomum subulatumRoxb.[Zingiberaceae]; MT-1592 Amorphophallus kachinensis Engl. \& Gehrm. [Araceae]; MT-1587 Aralia armata (Wall. ex G. Don) Seem. [Araliaceae]; $M T-1552$

Ardisia solanacea (Poir.) Roxb. [Primulaceae]; MT-1680

Arenga obtusifolia Mart.[Arecaceae]; MT-1557

Artemisia indica Willd. [Asteraceae]; MT-1646

Artocarpus heterophyllus Lam.[Moraceae]; MT-1625

Artocarpus lacuchaBuch.Ham. [Moraceae]; MT-1779

Asystasiella neesiana (Wall.) Lindau [Acanthaceae]; MT-1742

Auricularia auricula-judae (Bull.) J.Schrot[Auriculariaceae]; MT-1717 Auricularia polytricha (Mont.) Sacc. [Auriculariaceae]; MT-1718

Baccaurea ramiflora Lour. [Phyllanthaceae]; MT-1629

Balanophora dioica R.Br. ex Royle [Balanophoraceae]; MT-1558

Bambusa tulda Roxb. [Poaceae] ; MT-1631

Bauhinia purpurea L. [Fabaceae]; MT-3100

Bauhinia variegataL. [Fabaceae]; MT-1745

Beaumontia grandiflora Wall. [Apocynaceae]; MT-1636

Begonia aborensis Dunn [Begoniaceae]; MT-1595

Begonia acetosella Craib [Begoniaceae]; MT-1638

Begonia palmata D.Don [Begoniaceae]; MT-1639

Begonia roxburghii A.DC. [Begoniaceae]; MT-1594

Begonia silhetensis (A.DC.) C.B. Clarke [Begoniaceae]; MT-3101

Benincasa hispida (Thunb.) Cogn. [Cucurbitaceae]; MT-1765

Bidens pilosa L. [Asteraceae]; MT-1553

Eetki-daali $\quad \mathrm{Sf}$

Belang

Raami

Obul

Koko-nyorung

Koko-nyorung

Bureng

Taruk-langkaer P

Dibang

HP

Ogok

Ogok

Dongko-riyo

Sisibaying

Dumbo-leepang HP

Dumbo-lepang HP

Sisibaying

Sisibaying

$\mathrm{Pau} /$ paar

Tasso-lepyo

Eyok aain
Ts, Sd

F: Tender shoot and aromatic seeds edible

$\mathrm{H}$ : Preparation of bait for rodents and birds

F. Edible

F: Young ones edible

p, Vn, Fd: Stem pith and leaves as fodder for pigs and cattle;

LSP HHM: Prepare broom with mid-vein of leaf pinnae; black

fibers from leaf-sheath used to prepare local hats (Leb-ro), backpack (Tali) cover and broom; M: brown powder of

leaf sheath applied topically on cuts and wounds for quick healing

Lf, Tw M: Leaf-paste took orally in stomach disorder; RBC: twigs used in rituals performing on funeral

C: Trunk suitable for house-poles, big mortar (Kipar), and pestles (Eeging) for paddy dehusking

F: Taken raw when ripe, sour

F: Cooked as a vegetable

F: Cooked and eaten

F: Cooked and eaten

F: Aril on seeds edible

Mst: Chewed as chewing gum

Ts, Cm F: Young shoots edible; M: fermented shoot used topically

in inflammation, burns, and insect bites; HHM: culms for

handicraft and construction

F: Cooked as a vegetable

F: Cooked as a vegetable

RBC: To decorate traditional hats "Leebro"'-worn during

war dance (Taapu)

F: Eaten raw;

M: Dizziness, headache: eaten raw

F: Eaten raw, sour; M: Eaten raw against dizziness and headache

F: Eaten, sour

do-

F: Eaten raw, sour; M: Also eaten raw against dizziness and headache

F: Cooked as a vegetable

F: Cooked as a vegetable

M: crushed paste nixed with fresh dung of Bos frontalis and clean water from natural spring is applied on the

forehead to treat malaria

Fd: Fodder for Bos front 


\begin{tabular}{|c|c|c|c|c|c|c|}
\hline Boehmeria pilosiuscula (Blume) Hassk. [Urticaceae]; MT-1739 & Nyot-kyang & S & Lf & Fd: Fodder for Bos frontalis & $\mathrm{N}$ & 0.017 \\
\hline Boeica fulva C.B. Clarke [Gesneriaceae]; MT-1704 & Jongkot & $\mathrm{S}$ & Lf & Mst: Chewed raw as a substitute for betel leaves & $\mathrm{N}$ & 0.017 \\
\hline Bombax ceibaL. [Malvaceae]; MT-1699 & Hingyo gyomur & $\mathrm{T}$ & $\mathrm{Fr}$ & HHM: Seed floss as stuffing material for pillows & $\mathrm{N}$ & 0.017 \\
\hline Brachystemma calycinum D. Don [Caryophyllaceae]; MT-1746 & Okin-parin & HA & $\mathrm{Lf}$ & $\begin{array}{l}\text { Packed in Phrynium pubinerve leaves, warmed and locally } \\
\text { applied cure cracked sole }\end{array}$ & $\mathrm{N}$ & 0.017 \\
\hline Brassaiopsis glomerulata (Blume) Regel [Araliaceae]; MT-1579 & Tagor & $\mathrm{T}$ & $\mathrm{Sp}$ & $\begin{array}{l}\text { RBC: Dried pith cut into small square blocks to decorate } \\
\text { traditional hat "Leebro",--worn during war dance (Taapu) }\end{array}$ & $\mathrm{N}$ & 0.017 \\
\hline Brassica juncea (L.) Czern [Brassicaceae]; MT-1791 & Pettu & HA & $\mathrm{Sd}$ & RBC: Burnt to protect the home from evil forces & $\mathrm{E}$ & 0.017 \\
\hline Brassica nigra (L.) K.Koch [Brassicaceae]; MT-1771 & Pettu tulang & HA & $\mathrm{Sd}$ & RBC: Burnt to protect the home from evil forces & $\mathrm{E}$ & 0.017 \\
\hline $\begin{array}{l}\text { Brugmansia suaveolens (Humb. \& Bonpl. ex Willd.) Sweet } \\
\text { [Solanaceae]; MT-1546 }\end{array}$ & Toti & $\mathrm{S}$ & Wh & $\begin{array}{l}\text { Fc: To barricade against trespassing of animals through } \\
\text { paddy field [plants poisonous, so animals so avoid going } \\
\text { near it] }\end{array}$ & $\mathrm{E}$ & 0.017 \\
\hline $\begin{array}{l}\text { Bryophyllum pinnatum (Lam.) Oken [Kalanchoe pinnata (Lam.) Pers.] } \\
\text { [Crassulaceae]; MT-1650 }\end{array}$ & Eme kusureng & $\mathrm{HP}$ & $\mathrm{Lf}$ & M: Sap applied on burns and inflammation & $\mathrm{E}$ & 0.017 \\
\hline Cajanus cajan (L.) Millsp. [Fabaceae]; MT-1769 & Peradh & $\mathrm{S}$ & $\mathrm{Sd}$ & F: Cooked as pulse & $\mathrm{N}$ & 0.017 \\
\hline \multirow[t]{2}{*}{ Calamus erectus Roxb. [Arecaceae]; MT-1562 } & Tara & $\mathrm{L}$ & $\begin{array}{l}\text { Ts, Fr, Lf, } \\
\text { St }\end{array}$ & F: Raw as well as roasted tender shoots edible; fruits sour; & $\mathrm{N}$ & 0.051 \\
\hline & & & & $\begin{array}{l}\text { C: Leaves for thatching; HHM: Stem to prepare local } \\
\text { handicrafts }\end{array}$ & & \\
\hline Calamus flagellum Griff. ex Mart. [Arecaceae]; MT-1541 & Yoyi & $\mathrm{L}$ & $\mathrm{Ts}, \mathrm{Fr}, \mathrm{St}$ & $\begin{array}{l}\text { F: Tender shoots and ripe fruits edible; HHM: Prickly } \\
\text { smoked stem used as a grinder }\end{array}$ & $\mathrm{N}$ & 0.034 \\
\hline $\begin{array}{l}\text { Callicarpa arborea Roxb. } \\
\text { [Lamiaceae]; } M T-3102\end{array}$ & Lalu & $\mathrm{T}$ & $\mathrm{Br}$ & $\begin{array}{l}\text { Mst: Bark has chewed with Rubus moluccanus leaves as a } \\
\text { substitute for betel nut }\end{array}$ & $\mathrm{N}$ & 0.017 \\
\hline Canarium strictum Roxb. [Burseraceae]; MT-1687 & Hilum & $\mathrm{T}$ & Fr, $\operatorname{Re}$ & $\begin{array}{l}\text { F: Fruits edible; } \mathrm{O}(\mathrm{MR}) \text { : dry resin as fragrant incense or as } \\
\text { mosquito repellant }\end{array}$ & $\mathrm{N}$ & 0.034 \\
\hline Canna indica L. [C. edulis Ker Gawl.], [Cannaceae]; MT-1707 & Kampir eengin & $\mathrm{HP}$ & $\mathrm{Rh}$ & F: Cooked and eaten & $\mathrm{N}$ & 0.017 \\
\hline Capparis multiflora Hook. f. \& Thomson [Capparaceae]; MT-1776 & Remsap & CS & $\mathrm{Fl}$ & $\begin{array}{l}\text { RBC: Its blooming indicate the time for paddy } \\
\text { transplantation }\end{array}$ & $\mathrm{N}$ & 0.017 \\
\hline Capsicum frutescens L. [Solanaceae]; MT-1767 & Peepit marsi & HP & $\mathrm{Fr}$ & F: As spice in different food preparations & E & 0.017 \\
\hline Cardamine hirsuta L. [Brassicaceae]; MT-1751 & Oram-petsik & HA & Wh & F: Cooked as a green vegetable & $\mathrm{N}$ & 0.017 \\
\hline Carex baccans Nees [Cyperaceae]; MT-1677 & $\begin{array}{l}\text { Gemin- } \\
\text { taabeng/tapok }\end{array}$ & HP & Wh & $\begin{array}{l}\text { RBC: Believed that Carexbaccans and Saccharum } \\
\text { aruninaceum came from the same ancestor, so they use } \\
\text { whole plants together in funeral rituals }\end{array}$ & $\mathrm{N}$ & 0.017 \\
\hline Caryota urens L. [Arecaceae]; MT-1570 & Tamak & $\mathrm{P}$ & St & $\begin{array}{l}\text { HHM: Split stem used for making traditional weaving } \\
\text { sword shape material (Sumpa) and hunting equipment }\end{array}$ & $\mathrm{N}$ & 0.017 \\
\hline Casearia varecaRoxb. [Salicaceae]; MT-1597 & Sipe-siile & $\mathrm{S}$ & Fr & $\begin{array}{l}\text { H: Ripe ones used as bait in the traditional trap }(E t k u) \text { to } \\
\text { hunt birds and rodents }\end{array}$ & $\mathrm{N}$ & 0.017 \\
\hline Castanopsis indica (Roxb. ex Lindl.) A.DC. [Fagaceae]; $M T-1602$ & Siirang & $\mathrm{T}$ & En & F: Endosperm eaten raw or roasted & $\mathrm{N}$ & 0.017 \\
\hline Castanopsis purpurella (Miq.) N.P.Balakr. [Fagaceae]; MT-1618 & Angke & $\mathrm{T}$ & En & F: Endosperm eaten raw or roasted & $\mathrm{N}$ & 0.017 \\
\hline Centella asiatica (L.) Urb. [Apiaceae]; MT-1711 & Kiiling kiipum & HA & Wh & $\begin{array}{l}\text { M: Plant paste is taken orally to treat gastrointestinal } \\
\text { disorder }\end{array}$ & $\mathrm{N}$ & 0.017 \\
\hline $\begin{array}{l}\text { Chassalia curviflora var.ophioxyloides (Wall) Deb \& B.Krishna } \\
\text { [Rubiaceae]; } M T-1724\end{array}$ & $\begin{array}{l}\text { Longkin/sityung } \\
\text { oying }\end{array}$ & $\mathrm{S}$ & Ts & F: Cooked as a vegetable & $\mathrm{N}$ & 0.017 \\
\hline Chenopodium album L. [Amaranthaceae]; MT-1700 & Jili-mili & HA & Ts & F: Cooked as a vegetable & $\mathrm{N}$ & 0.017 \\
\hline Chenopodium giganteum D.Don [Amaranthaceae]; MT-1616 & Amateng & HA & Ts & F: Cooked as a vegetable & $\mathrm{N}$ & 0.017 \\
\hline
\end{tabular}




\begin{tabular}{|c|c|c|c|c|c|c|}
\hline $\begin{array}{l}\text { Choerospondias axillaris (Roxb.) B.L.Burtt \& A.W.Hill } \\
\text { [Anacardiaceae]; } M T-1529\end{array}$ & Belam & $\mathrm{T}$ & Fr & $\begin{array}{l}\text { F: Ripe ones sweet and edible; } \\
\text { H: Also used as bait for hunting deer }\end{array}$ & $\mathrm{N}$ & 0.034 \\
\hline Chromolaena odorata (L.) R.M.King \& H.Rob. [Asteraceae]; MT-1695 & Ingkir & Sf & $\mathrm{Lf}$ & Paste applied on cuts as a hemostat & $\mathrm{E}$ & 0.017 \\
\hline Cinnamomum bejolghota (Buch.-Ham.) Sweet [Lauraceae]; MT-1690 & Hipir ayin & $\mathrm{T}$ & Fr & F: Young ones steamed as chutney & $\mathrm{N}$ & 0.017 \\
\hline Cinnamomum verum J.Presl [Lauraceae]; MT-1596 & Siri pori & $\mathrm{T}$ & $\mathrm{Br}$ & F: Aromatic bark as a spice & $\mathrm{E}$ & 0.017 \\
\hline Citrus $\times$ aurantium L. [Rutaceae]; MT-1715 & Kintirang & $\mathrm{T}$ & Fr, $\mathrm{Sd}$ & $\begin{array}{l}\text { F: Ripe ones eaten raw, sweet; } \mathrm{H} \text { : Seeds as bait in } \\
\text { traditional hunting trap }(E e t k u) \text { for rodents }\end{array}$ & $\mathrm{E}$ & 0.034 \\
\hline Citrus indica Yu. Tanaka [Rutaceae]; MT-1681 & Goyeng-hingkiin & $\mathrm{T}$ & Fr & F: Ripe ones sour, taken raw & $\mathrm{N}$ & 0.017 \\
\hline Citrus latipes (Swingle) Yu.Tanaka [Rutaceae]; MT-1809 & Hinnong/hingkom & $\mathrm{T}$ & Fr & F: Taken raw, sour, & $\mathrm{N}$ & 0.017 \\
\hline Citrus maxima (Burm.) Merr. [Rutaceae]; MT-1714 & Kintee & $\mathrm{T}$ & Fr, Tw & $\begin{array}{l}\text { F: Ripe ones eaten raw; RBC: Twigs used in rituals done } \\
\text { for health and prosperity and to restrict negative forces }\end{array}$ & $\mathrm{N}$ & 0.034 \\
\hline Citrus medicaL.[ Rutaceae]; MT-1688 & Hingkom & $\mathrm{S}$ & Fr & F: Taken raw, sour & $\mathrm{N}$ & 0.017 \\
\hline ClathrusruberP.Micheli ex pers. [Phallaceae]; MT-1518 & Memut-taput & $\mathrm{F}$ & FB & Their bizarre looks signify an evil nature & - & 0.017 \\
\hline Clerodendrum colebrookeanum Walp [Lamiaceae]; MT-1517 & Ongin & $S$ & $\mathrm{Lf}$ & $\begin{array}{l}\text { F: Cooked as a vegetable; M: In hypotension and cough: } \\
\text { cooked and eaten }\end{array}$ & $\mathrm{N}$ & 0.034 \\
\hline Coix lacryma-jobi L. [Poaceae];MT-1805 & Ayak & HA & $\mathrm{Sd}$ & F: Fermented Nokyin is prepared from self-made yeast 'siye. & $\mathrm{N}$ & 0.017 \\
\hline Colocasia esculenta (L.) Schott [Araceae]; MT-1651 & $\begin{array}{l}\text { Enge }(\text { corm); } \\
\text { Ngerek/ ngekong } \\
\text { (tender leaf) }\end{array}$ & HP & $\mathrm{Cr}, \mathrm{Lf}$ & F: Corm and young leaves cooked as a vegetable & $\mathrm{N}$ & 0.017 \\
\hline Corchorus capsularis L. [Malvaceae]; MT-1516 & Olab & HA & $\mathrm{Lf}$ & F: Takencooked as vegetable & $\mathrm{N}$ & 0.017 \\
\hline Cordia dichotoma G.Forst [Boraginaceae]; MT-1514 & Jongge & $\mathrm{T}$ & Fr & O: Sticky mesocarp as glue for light materials like paper & $\mathrm{N}$ & 0.017 \\
\hline Crassocephalum crepidioides (Benth.) S.Moore [Asteraceae]; MT-1515 & Eeli & HA & Ts & F: Taken cooked as a vegetable & $\mathrm{E}$ & 0.017 \\
\hline Cucumis melo L. [Cucurbitaceae]; MT-1513 & Mari & $\mathrm{CH}$ & Fr & F: Ripe ones eaten raw & $\mathrm{N}$ & 0.017 \\
\hline Cucurbita maxima Duchesne [Cucurbitaceae]; MT-1512 & $\begin{array}{l}\text { Tapa (fruit); } \\
\text { Payin (tender } \\
\text { shoot) }\end{array}$ & $\mathrm{CH}$ & Fr, Ts & F: Cooked and served as a vegetable & $\mathrm{E}$ & 0.017 \\
\hline Curcuma caesia Roxb. [Zingiberaceae]; MT-1510 & Kala haaldi & HP & $\mathrm{Rh}$ & $\begin{array}{l}\text { M: Raw paste in water taken internally in empty stomach } \\
\text { to cure acidity and gastritis }\end{array}$ & $\mathrm{N}$ & 0.017 \\
\hline Curcuma longa $\mathrm{L}$. [Zingiberaceae]; MT-1511 & Haaldi & HP & $\mathrm{Rh}$ & $\begin{array}{l}\text { M: Paste of rhizome is applied on the incision during } \\
\text { vasectomy and tubectomy of cattle and even for bone } \\
\text { fracture }\end{array}$ & $\mathrm{N}$ & 0.017 \\
\hline $\begin{array}{l}\text { Cyathea gigantea (Wall. ex Hook.) Holttum [Alsophila gigantea Wall. } \\
\text { ex Hook.] } \\
\text { [Cyatheaceae]; MT-1519 }\end{array}$ & Ngepi & $\mathrm{T}$ & Fn & $\begin{array}{l}\text { RBC: Believe that gates prepared with these fronds prevent } \\
\text { the spread of infectious diseases inside the boundary }\end{array}$ & $\mathrm{N}$ & 0.017 \\
\hline $\begin{array}{l}\text { Cyathea spinulosa Wall. ex Hook. [Alsophila spinulosa (Wall. ex } \\
\text { Hook.) R.M.Tryon [Cyatheaceae]; MT-1554 }\end{array}$ & Tasse & $\mathrm{T}$ & Sp & F: Taken as a famine food & $\mathrm{N}$ & 0.017 \\
\hline $\begin{array}{l}\text { Debregeasia longifolia (Burm.f.) Wedd. } \\
\text { [Urticaceae]; MT-1741 }\end{array}$ & Nyot-kyang & $\mathrm{S}$ & $\mathrm{Lf}$ & Fd: Fodder for Bos frontalis & $\mathrm{N}$ & 0.017 \\
\hline Deeringia amaranthoides (Lam.) Merr. [Amaranthaceae]; MT-1747 & Oko-libo & CS & Ts & F: Cooked and served as a vegetable & $\mathrm{N}$ & 0.017 \\
\hline
\end{tabular}


Dendrocalamus hamiltonii Nees \& Arn. ex Munro [Poaceae]; MT-1643 Eemo (plant), Etiing (young shoot); Ekung (fermented

shoot)

Dendrocnide sinuata (Blume) Chew [Urticaceae]; MT-1762

Pantu tarung

Ts, $\mathrm{Cm}$ F: Young' and 'Eyub.'

F. Young shoots edible, fermented bamboo-shoot (Ekung), dried fermented-shoot $(E y u b)$; M: fermented shoots applied on burns and insect bites; HHM: culms used for handicraft and construction

M: Infected wounds of Bos frontalis is beaten with its leaves (covered with stinging hairs) to kill infecting organisms

Dicranopteris linearis (Burm.f.) Underw. [Gleicheniaceae]; MT-1559 Tarong

Dillenia indica L. [Dilleniaceae]; MT-1593

Dimetia scandens (Roxb.) R.J.Wang [Rubiaceae]; MT-1697

Sompa

Inkip-inkop

$\mathrm{T}$

Dinochloa macclellandii (Munro) Kurz [Poaceae]; MT-1581

Tagir

Cy

$\mathrm{Ts}, \mathrm{Tu}$

: Long petioles decomposed under mud, fibrous pith will turn dark blue and used as a belt (Beying), anklets, and bangles (Kongge) in earlier times

F: Acrescent calyx eaten raw

F: Cooked as a vegetable; M: Tubers used for curing gastrointestinal disorders

C: Culm used as a rope to tie roofing leaves (Ekap) with the supporting pillars (Papir); HHM: Household articles; RBC: Rituals in ceremonies related to health issues

Dioscorea alata L. [Dioscoreaceae]; MT-1778 Dioscorea bulbifera L. [Dioscoreaceae]; MT-1652

Rame

Dioscorea esculenta (Lour) Burkill [Dioscoreaceae]; MT-1832

Engin

Dioscorea pentaphylla L. [Dioscoreaceae]; MT-1544

Diplazium esculentum (Retz.) Sw. [Athyriaceae]; MT-1577

Duabanga grandiflora (DC.) Walp. [Lythraceae]; MT-1716

Duchesnea indica (Jacks.) Focke [Rosaceae]; MT-1648

Elatostema dissectum Wedd. [Urticaceae]; MT-1825

Eleusine coracana (L.) Gaertn. [Poaceae]; MT-1730

Entada parvifolia Merr. [Fabaceae]; MT-1774

Entada phaseoloides (L.) Merr. [Fabaceae]; MT-1773

Equisetum diffusum D.Don [Equisetaceae]; MT-1603

Erigeron canadensis L. [Asteraceae]; MT-1696

Eryngium foetidum L. [Apiaceae]; MT-1614

Erythrina stricta Roxb.[Fabaceae]; MT-1582

F: Tuberous and served cooked as a vegetable or roasted

F: Tuberous and served cooked as a vegetable or roasted

F: Tuberous and served cooked as a vegetable or roasted

F: Roasted to eat

F: Young ones cooked as a vegetable

C: Used as poles

F: Ripe ones eaten raw, watery

F: Eatenas salad or cooked as a vegetable

RBC: Burnt in fire or spread on the floor to scare the evil

spirits

O: Paste worked as a soap

Fh: Root-bark used for stupefying fishes

$\mathrm{RBC}$ : In rituals related to health and prosperity

F: Cooked and served as a vegetable

F: Added to prepared food and salad for flavoring

RBC: Beliefs, plant forms a boundary between human
Uli

Takang

Kobo

Eki-tangkin

Onu

Mirung

Riilok

Riipik

Sedum tap

sisi dangki

Ingko-bodong HA

Ritak/Migom ori HP

Tagat

$\mathrm{T}$

(Nonflowering

state), Galling

Appun

(Blomming

state)

beings and souls; mostly planted near graveyards so that

the departed soul leave the village and move forward for

the spiritual world and its blooming of the flower indicates

the time for broadcasting bean seeds 
Byakok

S

Fagopyrum esculentum Moench [Polygonaceae]; MT-1723 Ficus auriculata Lour. [Moraceae]; MT-1756

Ficus crassiramea (Miq.) Miq. [Moraceae]; MT-1601

Ficus geocarpa Teijsm. Ex. Miq. [Moraceae]; MT-1641 Ficus heteropleura Blume [Moraceae]; MT-1790 Ficus hispida L.f. [Moraceae]; MT-1764

Ficus oligodon Miq. [Moraceae]; MT-1761 Ficus religiosa L. [Moraceae]; MT-1600

Ficus semicordata Buch. Ham. ex Sm.[Moraceae]; MT-1574 Ficus simplicissima Lour. [Moraceae]; MT-1575 Ficus tinctoria G.Forst. [Moraceae]; MT-1599

Ficus variegata Blume [Moraceae]; MT-1588

Ficus virens Aiton [Moraceae]; MT-1833

Fissistigma bicolor (Roxb.) Merr. [Annonaceae]; MT-1816 Fissistigma polyanthum (Hook. f. \& Thomson) Merr. [Annonaceae]; MT-1772

Garcinia anomala Planch. \& Triana [Clusiaceae]; MT-1561

Garcinia lanceifolia Roxb. [Clusiaceae]; MT-1560

Garcinia pedunculata Roxb. ex Buch. Ham. [Clusiaceae]; MT-1586

Glycine $\max (\mathrm{L}$.$) Merr. [Fabaceae]; MT-1770$

Gnaphalium polycaulon Pers. [Asteraceae]; MT-1758

Gonostegia hirta (Blume ex Hassk.) Miq. [Urticaceae]; MT-1755

Gynocardia odorata R.Br. [Achariaceae]; MT-1731

Gynura cusimbua (D.Don) S.Moore [Asteraceae]; MT-1743

Helixanthera parasitica Lour. [Loranthaceae]; MT-1555

Helminthostachys zeylanica (L.) Hook.[Ophioglossaceae]; MT-1620

Heteropanax fragrans (Roxb.) Seem. [Araliaceae]; MT-1656

Lompuk

Paapop

Siirot

HA

$\mathrm{T}$

$\mathrm{T}$

Ee berii

Pasuk-payukleki $\mathrm{T}$

tapang

Pameng

Siirot

$\mathrm{T}$
$\mathrm{T}$

Lx

Lf

Fr

$\mathrm{Wh}$

Hodgsonia macrocarpa (Blume) Cong. [Cucurbitaceae]; MT-1552

Hornsted
MT-1627
Takuk

Takpi

Siirot

Taasik

Rika-riya

Rika-riya

Taraak

Taraak

Tabing

Peron-rontung HA

Paaput

Oyik

Mondo-tulpi

Ogen

Tasik

Asi-bisi

Gaatum-bopang $\mathrm{T}$

Tatar-api

Bele-belaak

field, animals avoid it for its poisonous nature. Also, its

showy bracts add to the beauty

M: Latex is pasted with Nicotiana tabaccum leaves to apply on infected wounds of cattle

F: Young leaves as a vegetable

F: Ripe hypanthodia and tender shoots edible

RBC: Beliefs, jungle spirit live on this tree, so people do

not cut the tree, if they cut it then jungle spirit will get

angry and harm the villagers

F: Ripe hypanthodia edible, sweet

$\mathrm{H}$ : Ripe hypanthodia used as bait for birds

F: Cooked and mixed with soya beans for quick

fermentation

F: Ripe hypanthodia edible, sweet

RBC: Beliefs, jungle spirit live on this tree, so people do

not cut it, if they cut it then jungle spirit will get angry and

harm the villagers

F: Ripe hypanthodia edible, sweet

F: Mixed with soybeans for fermentation

RBC: As in Ficus religiosa

F: Ripe hypanthodia edible, sweet

F: Cooked and served as a vegetable

F: Ripe fruits sweet, taken raw

F: Eaten ripe one raw, sweet

F: Edible, sour

F. Edible, sour

F: Ripe ones eaten raw, sweet; M: Smoked fruit wall taken orally to treat gastrointestinal problems

F: Local recipe naming Peron/ Ronyang (fermented soya

bean) is made of its seeds

F. Cooked as a vegetable

F: Cooked as a vegetable

Fh: Paste mixed in water for stupefying fishes

F: Cooked as a vegetable

F: Ripe ones eaten raw, sweet

F: Young ones cooked as a vegetable

$\mathrm{H}$ : As bait to trap rodents and birds

F: Embryo edible after cooking

F: Flower buds and fruits eaten raw
0.017

0.017

0.017

0.017

0.017

0.017

0.017

0.017

0.017

0.017

0.017

0.017

0.017

0.017

0.017

0.034

0.017

0.017

0.017

0.017

0.017

0.017

0.017

0.017

0.017 


Wh, Lf

Hydrocotyle himalaica P.K.Mukh. [Araliaceae]; MT-1830 Hydrocotyle javanica Thunb.[Araliaceae]; MT-1712

$\begin{array}{ll} & \text { HA } \\ \text { Kiling-kiipum } & \text { HA } \\ \text { Nanor-tangkor } & \text { HA } \\ \text { Eengin-taari } & \text { HG } \\ \text { Pangkang takeng } & \text { HP } \\ \text { Ronjab } & \mathrm{CH} \\ \text { Eepum/eejuk/ } & \mathrm{CH} \\ \text { giri } & \end{array}$

Wh

F: Whole plants edible; M: leaves taken raw orally in gastrointestinal disorders

Impatient bracteolata Hook.f. [Balsaminaceae]; MT-1735

Ipomoea batatas (L.) Lam. [Convolvulaceae]; MT-1644

Kaempferia galangaL. [Zingiberaceae]; MT-3111

Lablab purpureus (L.) Sweet [Fabaceae]; MT-1611

Lagenaria siceraria (Molina) Standl. [Cucurbitaceae]; MT-1645

giri

Fh: Paste mixed in water for stupefying fish

Wh Fh: Paste mixed in water for stupefying fish

F: Tender shoots serve as a vegetable

Sh, Tu F: Both served as a vegetable

Rh M: Paste applied on skin to cure itching

Fr F: Cooked as a vegetable

Fr F: Cooked as a vegetable; HHM: Shell of matured dried

fruits used as vessels: names and uses of vessels depend on

the shape and are named as AsiGiri (water bottle): Eejuk

for spoon-shaped and Eepum for urn shape meant for

different purposes

Laphangium affine (D.) Tzvelev [Asteraceae]; MT-1757

Paaput

F: Cooked as a vegetable

Lentinula edeodes (Berk.)Pegler [Marasmiaceae]; MT-172I

Lolum

Toti

F: Cooked and eaten

Leucosceptrum canum $\mathrm{Sm}$.

St

[Lamiaceae]; MT-1545

RBC: Believes, when the soul moves out from the human

body by accident, in such cases, they perform rituals (Leyo Goknam) in which the twig of the plant is used that acts as a pathway for the soul to come back to the sufferer

Lindenbergia hookeri C.B.Clarke ex Hook.f. [Plantaginaceae]; MT-1522 Litsea cubeba (Lour.) Pers. [Lauraceae]; MT-1777

Livistona jenkinsiana Griff.

Fl F: Edible, sour

[Arecaceae]; MT-1520

Rayil, tayir

Macaranga cuspidata Boivin ex Baill. [Euphorbiaceae]; MT-1521

Taek

F: As a condiment, strongly aromatic

Lf, Fr F: Tender leaves and fermented fruits edible

$\mathrm{C}$ : Leaves widely used for thatching houses

Fr $\quad \mathrm{H}$ : As bait for birds and rodents

Lagar

Maclura cochinchinensis (Lour.) Corner [Moraceae]; MT-1808 Maesa indica (Roxb.) A.DC. [Primulaceae]; MT-1654

Tanyum-tang

Etjun-jayun

Fr $\quad$ F: Ripe ones eaten, sweet

Mangifera sylvatica Roxb. [Anacardiaceae]; MT-1686

Manihot esculenta Crantaz.

[Euphorbiaceae]; $M T-1598$

Melastoma malabathricum L. [Melastomataceae]; MT-1709

Hidum-tagung $\mathrm{T}$

Singyo engiin/ S

Situng eengin

Kasii rai

Fr, Ts F: Ripe fruits and tender shoots eaten raw

Fr F: Ripeones edible, sour

Ts, Rs $\quad$ F: Tender shoot as vegetable and tuberous root used for local wine (Nokyin)

Melothria trilobata Cogn.

[Cucurbitaceae]; MT-1635

Dongkong

Fr, Fl

ocal wine (Nokyin)

time for broadcasting of paddy seeds

$\mathrm{Fr}, \mathrm{Tu} \quad \mathrm{F}$ : Ripe fruits eaten raw; M: tuber ate raw in

gastrointestinal disorders

Microtropis discolor (Wall.) Arn. [Celastraceae]; MT-1827

Mikania micrantha Kunth [Asteraceae]; MT-1642

Molineria capitulata (Lour.) Herb. [Curculigo capitulata (Lour.)

kayong

Kuntze], [Hypoxidaceae]; $M T-1548$

Molineria prainiana Deb [Curculigo prainiana (Deb) Bennet \&

Raizada] [Hypoxidaceae]; $M T-1815$

Morus alba L. [Moraceae]; MT-1789

Morus macroura Miq. [Moraceae]; MT-1647

Eeli
Tayek
Tayek
Nini-guti
Eeyum

$\mathrm{H}$ : Red seed used as bait for rodents

M: Taken orally to cure stomachache and dysentery

$\mathrm{O}$ : Leaf veins used as thread to stitch the scrotum of piglets

after castration

$\mathrm{O}$ : Leaf veins used as thread to stitch the scrotum of piglets

after castration

F: Ripe ones sweet, edible

M: Applied on burns and inflammation of the skin

T $\quad$ Fr




\begin{tabular}{|c|c|c|c|c|c|c|}
\hline Murdannia nudiflora (L.) Brenan [Commelinaceae]; MT-1693 & Hodog/golgi & HA & $\mathrm{Fl}$ & $\begin{array}{l}\text { RBC: Initiation of its flowering signifies the time for } \\
\text { broadcasting paddy seeds. Plants growing along the field } \\
\text { borders for demarcation }\end{array}$ & $\mathrm{N}$ & 0.017 \\
\hline Musa aurantiaca G.Mann ex Baker [Musaceae]; MT-1640 & Dumji & HP & Wh & $\begin{array}{l}\text { RBC: Believed that if a woman roams near or cuts the } \\
\text { plant, their stomach will ache }\end{array}$ & $\mathrm{N}$ & 0.017 \\
\hline Musa balbisiana Colla [Musaceae]; MT-1726 & $\begin{array}{l}\text { Ludum/kolung } \\
\text { (for group of } \\
\text { Musa sp.) }\end{array}$ & HP & In, Lf & $\begin{array}{l}\text { F: Spadix cooked as a vegetable; HHM: Leaf sheaths split } \\
\text { narrowly and dried to prepare mats; O: powdery substance } \\
\text { collected from the abaxial surface of the lamina is used to } \\
\text { reduce friction in a traditional loom }\end{array}$ & $\mathrm{N}$ & 0.034 \\
\hline Musa sanguinea Hook.f. [Musaceae]; MT-1760 & Paksum & HP & In & F: Young spadix cooked as a vegetable & $\mathrm{N}$ & 0.017 \\
\hline Mussaenda glabra Vahl [Rubiaceae]; MT-1547 & Tekdeng & $\mathrm{S}$ & Ts & F: Cooked as a vegetable & $\mathrm{N}$ & 0.017 \\
\hline Mussaenda roxburghii Hook. f. [Rubiaceae]; MT-1615 & Akshap & $\mathrm{S}$ & Ts & F: Cooked as a vegetable & $\mathrm{N}$ & 0.017 \\
\hline Myrica esculenta Buch.Ham. ex D.Don [Myricaceae]; MT-1551 & Tatir & $\mathrm{T}$ & Fr & F: Ripe ones eaten raw & $\mathrm{N}$ & 0.017 \\
\hline Nasturtium officinale R.Br. [Brassicaceae]; MT-1752 & Orgyam & HA & Tw & F: Leafy twigs cooked as a vegetable & $\mathrm{E}$ & 0.017 \\
\hline Neohouzeaua helferi (Munro) Gamble [Poaceae];MT-1834 & Tatpin & B & $\mathrm{Lf}$ & Fd: As fodder for Bos frontalis & $\mathrm{N}$ & 0.017 \\
\hline Nephelium lappaceum L.[Sapindaceae]; MT-1583 & Tadar & $\mathrm{T}$ & Fr & F: Ripe ones eaten raw, sour and sweet & $\mathrm{N}$ & 0.017 \\
\hline Nephrolepis cordifolia (L.) C.Presl [Nephrolepidaceae]; MT-1685 & Hidum huli & HP & $\mathrm{Tu}$ & $\begin{array}{l}\text { M: Potato under-ground tubers taken orally for urinary } \\
\text { tract infection }\end{array}$ & $\mathrm{N}$ & 0.017 \\
\hline Nicotiana rustica L. [Solanaceae]; MT-1684 & Haali & HP & $\mathrm{Lf}$ & O: Ground leaf is mixed with salt and then used to kill leeches & $\mathrm{E}$ & 0.017 \\
\hline Nicotiana tabacumL. [Solanaceae]; MT-1720 & Kuser & HA & Lf & $\begin{array}{l}\text { Mst: Dried leaves produce tobacco; M: salt is added on leaf } \\
\text { paste and then applied on infected wounds of cattle }\end{array}$ & $\mathrm{E}$ & 0.034 \\
\hline Ocimum basilicum L. [Lamiaceae]; MT-1576 & Take-mare & HA & Lf & F: Aromatic, used as a spice & $\mathrm{N}$ & 0.017 \\
\hline Oenanthe javanica (Blume) DC. [Apiaceae]; MT-1821 & - & HA & Ts & F: Cooked as a vegetable & $\mathrm{N}$ & 0.017 \\
\hline Ophioglossum reticulatum L. [Ophioglossaceae]; MT-1623 & Ayo-borkok & HG & Fn & F: Cooked as a vegetable & $\mathrm{N}$ & 0.017 \\
\hline Ophioglossum vulgatum L. [Ophioglossaceae]; MT-1622 & Ayo-borkok & HG & Fn & F: Cooked as a vegetable & $\mathrm{E}$ & 0.017 \\
\hline Oryza sativa L. [Poaceae]; MT-1617 & Ammo & HA & $\mathrm{Sd}$ & $\begin{array}{l}\text { F: Fermented rice (Nokyin) and country liquor (Yaka } \\
\text { Apong) are prepared using a self-made starter (siye); M: } \\
\text { applied on burn and inflammation of the skin }\end{array}$ & $\mathrm{E}$ & 0.034 \\
\hline Ostodes paniculata Blume [Euphorbiaceae]; MT-1556 & Tasi-gumbi & $\mathrm{T}$ & $\mathrm{Wh}$ & Fc: Planted for fencing & $\mathrm{N}$ & 0.017 \\
\hline Oxalis corniculata L. [Oxalidaceae]; MT-1781 & Piyag-hiyub & HA & $\mathrm{Fr}$ & M: Sap of fruit dropped in eyes to cure the infection & $\mathrm{E}$ & 0.017 \\
\hline Oxalis debilis Kunth [Oxalidaceae]; MT-1783 & Piiag-hiyub & HG & $\mathrm{Fl}, \mathrm{Bu}$ & F: Sour flower and watery bulbs eaten raw & $\mathrm{E}$ & 0.017 \\
\hline Pachyrhizus erosus (L.) Urb. [Fabaceae]; MT-1807 & Lodol, lodor & CS & $\mathrm{Tu}$ & F: Eaten raw, sweet & $\mathrm{E}$ & 0.017 \\
\hline Paederia foetida L. [Rubiaceae]; MT-1543 & $\begin{array}{l}\text { Yape taari/ riki } \\
\text { ringkom }\end{array}$ & CS & $\mathrm{Lf}$ & M: Taken orally to cure gastritis. & $\mathrm{N}$ & 0.017 \\
\hline Pandanus furcatus Roxb. [Pandanaceae]; MT-1788 & Tako & $\mathrm{T}$ & Sd, Lf & $\begin{array}{l}\text { F: Dried seed edible; HHM: Local mat Kurpyak is made of } \\
\text { dried leaves }\end{array}$ & $\mathrm{N}$ & 0.034 \\
\hline Paris polyphylla Sm. [Melanthiaceae]; MT-1737 & $\begin{array}{l}\text { Nyomrang } \\
\text { takeng (rhizome)/ } \\
\text { Kangkom oying } \\
\text { (leaves) }\end{array}$ & HG & $\mathrm{Lf}, \mathrm{Rh}$ & $\begin{array}{l}\text { F: Leaves served as a vegetable; M: Smoked or raw } \\
\text { rhizome taken orally in gastrointestinal disorders }\end{array}$ & $\mathrm{N}$ & 0.034 \\
\hline Perilla frutescens (L.) Britton [Lamiaceae]; MT-1733 & Namdung & HA & $\mathrm{Sd}$ & F: Eaten raw & $\mathrm{N}$ & 0.017 \\
\hline Persicaria barbata (L.) H.Hara [Polygonaceae]; MT-1632 & Diko-taamu & HA & $\mathrm{Wh}$ & Fh: Crushed and mixed in water to stupefy fishes & $\mathrm{N}$ & 0.017 \\
\hline $\begin{array}{l}\text { Persicaria capitata (Buch. Ham. ex D.Don) H.Gross [Polygonaceae]; } \\
\text { MT-1624 }\end{array}$ & Babing-kaling & HA & Fr & F: Ripe ones eaten raw & $\mathrm{N}$ & 0.017 \\
\hline Persicaria chinensis (L.) H.Gross [Polygonaceae]; MT-1787 & Babing-kaling & Sf & Wh & O: Crushed to use as hand wash & $\mathrm{N}$ & 0.017 \\
\hline
\end{tabular}




\begin{tabular}{|c|c|c|c|c|c|c|}
\hline Persicaria hydropiper (L.) Delarbre [Polygonaceae]; MT-1633 & Diko-taати & HA & $\mathrm{Wh}$ & Fh: Crushed and mixed in water to stupefy fishes & $\mathrm{N}$ & 0.017 \\
\hline Persicaria nepalensis (Meisn.) Miyabe [Polygonaceae]; MT-1623 & Babing-kaaling & HA & $\mathrm{Wh}$ & O: Crushed to use as hand wash & $\mathrm{N}$ & 0.017 \\
\hline PhallusindusiatusVent. [Phallaceae]; MT-1736 & Nyipong-tipur & FB & FB & RBC: Its odor signifies a woman's evil spirit (Nyipong) & - & 0.017 \\
\hline Phoebe cooperiana P.C. Kanjilal \& Das [Lauraceae]; MT-1563 & Tapir & $\mathrm{T}$ & Fr & F: Ripe ones eaten raw & $\mathrm{N}$ & 0.017 \\
\hline Phrynium pubinerve Blume [Marantaceae]; MT-1649 & Ekkam & HP & $\mathrm{Sd}, \mathrm{Lf}$ & $\begin{array}{l}\text { F: Seeds eaten raw; M: warmed leaves applied on muscle } \\
\text { pain and sprain; O: leaves used for packing, especially for } \\
\text { local rice cake 'Etting.' }\end{array}$ & $\mathrm{N}$ & 0.051 \\
\hline Phyllostachys mannii Gamble [Poaceae]; MT-1585 & Tabo & B & $\mathrm{Cm}$ & $\begin{array}{l}\text { HHM: Making walking sticks (Banggen): traditional too } \\
\text { leech, used for weeding in crop-fields }\end{array}$ & $\mathrm{N}$ & 0.017 \\
\hline Physalis lagascae Roem. \& Schult. [Solanaceae]; MT-1702 & Jojing belang & HA & Fr & F: Ripe ones eaten raw & $\mathrm{E}$ & 0.017 \\
\hline Pilea insolensWedd. [Urticaceae]; MT 1568 & Tango-lisak & HA & $\mathrm{Lf}$ & $\begin{array}{l}\text { F: Cooked leaves of Pilea insolens mixed with seeds of } \\
\text { Perillaocymoidesfor fermentation }\end{array}$ & $\mathrm{N}$ & 0.017 \\
\hline Pilea umbrosa Blume [Urticaceae]; MT-1749 & Oko-robo & HA & Ts & F: Cooked as a vegetable & $\mathrm{N}$ & 0.017 \\
\hline Piper betleoides C.DC. [Piperaceae]; MT-1780 & Popteng & $\mathrm{CS}$ & $\mathrm{Lf}$ & Mst: Chewed as a masticator & $\mathrm{N}$ & 0.017 \\
\hline Piper pedicellatum C.DC. [Piperaceae]; MT-1609 & Rori & CS & $\mathrm{Lf}$ & F: Cooked as a vegetable & $\mathrm{N}$ & 0.017 \\
\hline Plantago asiatica subsp. Erosa (Wall.) Z.Yu Li [Plantaginaceae]; MT-1637 & Donyi-borkor & HA & Lf & F: Ciiked as vegetable & $\mathrm{N}$ & 0.017 \\
\hline Pleurotus eous (Berk.) Sacc [Polyporaceae]; MT-1698 & Inyik & FB & FB & F: Cooked to eat & - & 0.017 \\
\hline Pleurotus ostreatus (Jacq.) P. Kumm [Polyporaceae]; MT-1699 & Inyik & FB & FB & F: Cooked to eat & - & 0.017 \\
\hline Pleurotus sajor-caju (Fr.) Fr. [Polyporaceae]; MT-1784 & Lengot & FB & FB & F: Cooked to eat & - & 0.017 \\
\hline Poikilospermum suaveolens (Blume) Merr. [Urticaceae]; MT-1744 & Ogik & $\mathrm{S}$ & Ts & F: Cooked as vegetable & $\mathrm{N}$ & 0.017 \\
\hline Polygonum molle D. Don [Polygonaceae]; MT-1710 & Kiibu-nanung & $\mathrm{S}$ & Ts & F: Eaten raw, sour & $\mathrm{N}$ & 0.017 \\
\hline Portulaca oleracea L. [Portulacaceae]; MT-1682 & Gubor-oying & HA & $\mathrm{Wh}$ & F: Cooked as a vegetable & $\mathrm{E}$ & 0.017 \\
\hline Pothos scandens L. [Araceae]; MT-1722 & Lomang looset & $\mathrm{E}$ & $\mathrm{Lf}$ & $\begin{array}{l}\text { M: Paste applied to treat bone fractures; RBC: if the patient } \\
\text { dreams it, then the fracture will heal quickly }\end{array}$ & $\mathrm{N}$ & 0.034 \\
\hline Pouzolzia sanguinea (Blume) Merr. [Urticaceae]; MT-1754 & Osik & Sf & Ts & F: Edible as vegetable & $\mathrm{E}$ & 0.017 \\
\hline Prunus persica (L.) Batsch [Rosaceae]; $M T-1719$ & Kombong & $\mathrm{T}$ & $\mathrm{Fl}$ & $\begin{array}{l}\text { RBC: Its blooming indicates the arrival of Kombong Poolo } \\
\text { month when the Unying/ Aran festival is celebrated }\end{array}$ & $\mathrm{E}$ & 0.017 \\
\hline Psidium guajava L. [Myrtaceae]; MT-1732 & Mudurang & $\mathrm{T}$ & Fr, Ts & $\begin{array}{l}\text { F: Ripe fruits edible; M: Tender shoots eaten raw to cure } \\
\text { gastrointestinal disorders }\end{array}$ & $\mathrm{E}$ & 0.034 \\
\hline Pteridium aquilinum (L.) Kuhn [Pteridaceae]; MT-1725 & Losup & HP & Fn & F: Young fronds cooked as a vegetable & $\mathrm{E}$ & 0.017 \\
\hline Pteris quadriaurita Retz. [Pteridaceae]; MT-1607 & Rukji & HP & Fn & $\begin{array}{l}\text { RBC: Beliefs, if a newly hatched chick's basket (Petir) is } \\
\text { covered with its fronds, then chicks will grow into red cocks }\end{array}$ & $\mathrm{N}$ & 0.017 \\
\hline Pteris tripartita Sw. [Pteridaceae]; MT-1606 & Rukji & HP & Fn & F: Young fronds as vegetable & $\mathrm{N}$ & 0.017 \\
\hline Pterospermum acerifolium (L.) Willd. [Malvaceae]; MT-1691 & Hipop & $\mathrm{T}$ & $\mathrm{Lf}, \mathrm{Br}$ & $\begin{array}{l}\text { O: For packing finger millets; bark for dyeing cotton } \\
\text { threads }\end{array}$ & $\mathrm{N}$ & 0.017 \\
\hline Pueraria montana (Lour.) Merr. [Fabaceae]; MT-1775 & Riidin & $\mathrm{L}$ & $\mathrm{Rs}, \mathrm{St}$ & $\begin{array}{l}\text { F: Root-tuber (Watery) eaten raw; M: fibers from stem- } \\
\text { bark applied on cuts and wounds; RBC: this fiber is used in } \\
\text { almost every ritual of the Tani clan and are tied on their } \\
\text { hand (on the right hand for the married and left hand for } \\
\text { unmarried) which is believed to be protective }\end{array}$ & $\mathrm{N}$ & 0.051 \\
\hline Rhaphidophora decursiva (Roxb.) Schott [Araceae]; MT-1571 & Talo & $\mathrm{E}$ & $\mathrm{Lf}$ & $\begin{array}{l}\text { RBC: Leaf twig is used to perform rituals after the bear } \\
\text { hunt for the departed soul to leave peacefully }\end{array}$ & $\mathrm{N}$ & 0.017 \\
\hline Rhaphidophora hookeri Schott [Araceae]; MT-1572 & Talo & $\mathrm{E}$ & Lf & $\begin{array}{l}\text { RBC: Used to perform rituals after the bear hunt for } \\
\text { departed souls to leave peacefully. }\end{array}$ & $\mathrm{N}$ & 0.017 \\
\hline
\end{tabular}




\begin{tabular}{|c|c|c|c|c|c|c|}
\hline Rhus chinensis Mill. [Anacardiaceae]; MT-1580 & Tagmo & $\mathrm{T}$ & Fr & M: Cooked with wild mushroom to avoid food poisoning & $\mathrm{N}$ & 0.017 \\
\hline $\begin{array}{l}\text { Rhynchotechum ellipticum (Wall. ex D.Dietr.) A.DC. [Gesneriaceae]; } \\
M T-1705\end{array}$ & Jongkot & $\mathrm{S}$ & Lf & Mst: Young leaves chewed as a substitute for betel leaves & $\mathrm{N}$ & 0.017 \\
\hline Rhynchotechum parviflorum Blume [Gesneriaceae]; MT-1814 & Jongkot & $\mathrm{S}$ & $\mathrm{Lf}$ & Mst: Young leaves chewed as a substitute for betel leaves & $\mathrm{N}$ & 0.017 \\
\hline $\begin{array}{l}\text { Rhynchotechum vestitum Wall. ex C.B. Clarke [Gesneriaceae]; MT- } \\
1706\end{array}$ & Jongkot & $\mathrm{S}$ & Fr & $\begin{array}{l}\text { F: Fruits watery, eaten raw; leaves fermented with soya } \\
\text { bean and both are eaten }\end{array}$ & $\mathrm{N}$ & 0.017 \\
\hline Ricinus communis L. [Euphorbiaceae]; MT-1678 & Gopo-golo & $\mathrm{S}$ & $\mathrm{Lf}$ & $\begin{array}{l}\text { M: Leaf is warmed on fire and placed on paining joint, } \\
\text { muscle, and sprain: bark of petiole also used as a bandage } \\
\text { to cure fractured bone of chick }\end{array}$ & $\mathrm{E}$ & 0.017 \\
\hline Ronabea emetica (L.f) A.Rich.[Rubiaceae]; MT-1728 & Margihop & $\mathrm{S}$ & Fr & F: Ripe ones edible, sweet & $\mathrm{E}$ & 0.017 \\
\hline Rorippa dubia (Pers.) H.Hara [Brassicaceae]; MT-1753 & Orgyam & HA & Lf & F: Cooked as a vegetable & $\mathrm{N}$ & 0.017 \\
\hline Rubus alceifolius Poir. [Rosaceae]; MT-1763 & Pasi-payi & S & Fr & F: Ripe ones eaten raw, sweet & $\mathrm{E}$ & 0.017 \\
\hline Rubus ellipticus Sm. [Rosaceae]; MT-1759 & Pakkom-tayin & $\mathrm{S}$ & Fr & F: Ripe oned eaten raw, sweet & $\mathrm{N}$ & 0.017 \\
\hline Rubus niveus Thumb. [Rosaceae]; MT-1542 & Yokpo-pongkung & $\mathrm{CS}$ & Fr & F: Ripe ones eaten raw, sweet & $\mathrm{N}$ & 0.017 \\
\hline Rubus paniculatus Sm. [Rosaceae]; MT-1569 & Tangkin & $\mathrm{CS}$ & Fr & F: Ripe ones eaten raw, sweet & $\mathrm{N}$ & 0.017 \\
\hline Rubus rosifolius Sm. [Rosaceae];MT-1831 & Tangkin & $\mathrm{S}$ & Fr & F: Ripe ones eaten raw & $\mathrm{N}$ & 0.017 \\
\hline Rubus sieboldii Blume [R. moluccanus L.], [Rosaceae]; MT-1567 & Tapa-tara & $\mathrm{S}$ & Fr, Lf & $\begin{array}{l}\text { F: Ripe fruits eaten raw, sweet: leaves as a substitute for } \\
\text { Piperbetel leaves }\end{array}$ & $\mathrm{N}$ & 0.017 \\
\hline Rubus sumatranus Miq. [Rosaceae]; MT-1713 & Kinbu-Beru & CS & Fr & F: Ripe ones edible, sweet & $\mathrm{N}$ & 0.017 \\
\hline Rumex maritimus L. [Polygonaceae]; MT-1750 & Okung & HA & Lf & F: Young leaves as a vegetable & $\mathrm{E}$ & 0.017 \\
\hline Saccharum arundinaceum Retz. [Poaceae]; MT-1566 & Tapii & HP & Wh & $\begin{array}{l}\text { RBC: Believed that it is the elder brother of Carex sp. and } \\
\text { the whole plant of both species are used in rituals } \\
\text { performing during the funeral }\end{array}$ & $\mathrm{N}$ & 0.017 \\
\hline Saccharum spontaneum L. [Poaceae]; MT-1782 & $\begin{array}{l}\text { Piko-pimur/ } \\
\text { aasi-pimur }\end{array}$ & HP & In & F: Roasted young inflorescence edible & $\mathrm{N}$ & 0.017 \\
\hline Saurauia armata Kurtz [Actinidiaceae]; MT-1619 & Anpum & $\mathrm{T}$ & Fr & F: Eaten raw, sweet & $\mathrm{E}$ & 0.017 \\
\hline Saurauia griffithii Dyer [Actinidiaceae]; MT-1829 & Taan & $\mathrm{T}$ & Fr & F: Ripe ones eaten raw & $\mathrm{N}$ & 0.017 \\
\hline Saurauia napaulensis DC. [Actinidiaceae]; MT-1590 & Taan & $\mathrm{T}$ & Fr, Tw & $\begin{array}{l}\text { F: Ripe fruits eaten raw, sweet; RBC: Twigs are used in } \\
\text { auspicious occasions, animal sacrifices, and rituals related } \\
\text { to prosperity }\end{array}$ & $\mathrm{N}$ & 0.034 \\
\hline Saurauia punduanaWall. [Actinidiaceae]; MT-1589 & Taan & $\mathrm{T}$ & Fr, Tw & $\begin{array}{l}\text { F: Ripe fruits eaten raw, sweet; RBC: Twigs are used in } \\
\text { auspicious occasions, animal sacrifices, and rituals related } \\
\text { to prosperity }\end{array}$ & $\mathrm{N}$ & 0.034 \\
\hline Saurauia sinohirsuta J.Q.Li \& Soejarto [Actinidiaceae]; MT-1819 & Anpum & $\mathrm{S}$ & Fr & F: Ripe ones, sweet, taken raw & $\mathrm{N}$ & 0.017 \\
\hline Sauropus androgynus (L.) Merr. [Phyllanthaceae]; MT-1676 & Gam-oying & $\mathrm{S}$ & $\mathrm{Lf}$ & F: Cooked as a vegetable & $\mathrm{N}$ & 0.017 \\
\hline $\begin{array}{l}\text { Schizostachyum pergracile (Munro) R.B.Majumdar [Poaceae]; MT- } \\
1835\end{array}$ & Madang & B & $\mathrm{Cm}$ & $\begin{array}{l}\text { HHM: Small fiber (Epang) made from the stem used for } \\
\text { house roofing to tie thatching materials }\end{array}$ & $\mathrm{N}$ & 0.017 \\
\hline Setaria italica (L.) P.Beauv. [Poaceae]; MT-1621 & Ayak & HA & $\mathrm{Sd}$ & $\begin{array}{l}\text { F: Used with the fermentation of rice (Nokyin) and for } \\
\text { country liquor (Yaka Apong); M: Fermented grains directly } \\
\text { applied on burnt skin }\end{array}$ & $\mathrm{E}$ & 0.034 \\
\hline Solanum aethiopicum L. [Solanaceae]; MT-1727 & Lutsaying & HA & Fr & F: Young fruits as vegetable & $\mathrm{E}$ & 0.017 \\
\hline Solanum erianthum D.Don [Solanaceae]; MT-1768 & Pepu sensu & $\mathrm{S}$ & Lf & $\begin{array}{l}\text { O: Leaves used for packing bananas for quick ripening and } \\
\text { protection from damage }\end{array}$ & $\mathrm{E}$ & 0.017 \\
\hline
\end{tabular}


Solanum nigrum L. [Solanaceae]; $M T$ - 1748

Solanum spirale Roxb. [Solanaceae]; MT-1527

Solanum torvum Sw. [Solanaceae]; MT-1526

Solanum viarum Dunal [Solanaceae]; MT-1525 Solanum villosum (L.) Willd. [Solanaceae]; MT-1524 Solanum violaceum Ortega [Solanaceae]; MT-1523

Spondias pinnata (L.f.) Kurz [Anacardiaceae]; MT-1530 Stapletonia seshagiriana (R.B.Majumdar) H.B.Naithani [Schizostachyum seshagiriana R.B. Majumdar], [Poaceae]; MT-1584 Stellaria media (L.)Vill. [Caryophyllaceae]; MT-1694

Stenochlaena palustris (Burm. ) Bedd. [Blechnaceae]; MT-1604

Sterculia lanceolata var. coccinea (Jack) Phengklai [Malvaceae]; MT- Taya 1549

Sterculia striatiflora Mast. [Malvaceae]; MT-1786

Stixis suaveolens (Roxb.) Pierre [Capparaceae]; MT-1613

Syzygium cumini (L.) Skeels [Myrtaceae]; MT-1703

Syzygium formosum (Wall.) Masam [Myrtaceae]; MT-1826

Syzygium fruticosum DC. [Myrtaceae]; MT-1828

Thelypteris parasitica (L.) Tardieu [Thelypteridaceae]; MT-1608

Themeda villosa (Lam.) A.Camas [Poaceae] ; MT-1820

Thladiantha cordifolia (Blume) Cong. [Cucurbitaceae]; MT-1738

Thysanolaena latifolia (Roxb. ex Hornem.) Honda [Poaceae]; MT-1708

Toddalia asiatica (L.) Lam. [Rutaceae]; MT-1675

Okomaman

Bangko

HA

Ts

f, Sd

\section{F. Tender shoots as a vegetable}

F: Leaves as a vegetable; $M$ : cooked leaves for

gastrointestinal disorder and hypertension; dried fruits are

taken orally in helminthiasis; warmed leaves applied on

Kodu/migom
kopi/kopi piit

Peeli-taang

HA

HA

Fr

Kopi piimik

S

Dorgu-dorge

Tabum

Hosir oying

Rukyo

Tayam

Tayam S

Rokpo ketum-

kelum

Jongkeng

Ponkan

Jongkeng

Rukji

Tase

Toxicodendron hookeri (K.C. Sahni \& Bahadur) C.Y. Wu \& T.L. Ming Bemo Anacardiaceae]; $M T-1626$

Trema Orientalis (L.) Blume [Cannabaceae]; MT-1628

Trevesia palmata (Roxb. ex Lindl.) Vis.[Araliaceae]; MT-1679

Urtica ardens Link [Urticaceae]; MT-1701

Urtica dioica L. [Urticaceae]; MT-1729

$\begin{array}{ll}\text { Bumlo } & \mathrm{T} \\ \text { Gorpak } & \mathrm{T} \\ \text { Jimang } & \mathrm{S} \\ \text { Matpe pereng } & \mathrm{S}\end{array}$

Vigna unguiculata (L.) Walp.[Fabaceae]; MT-1612

Viola betonicifolia Sm. [Violaceae]; MT-1540

Viola pilosa Blume [Violaceae]; MT-1539
Rondong

Jortung/japjor $\mathrm{HP}$

Jorsing/japjor HP 


\begin{tabular}{|c|c|c|c|c|c|c|}
\hline Wallichia oblongifolia Griff. [Arecaceae]; $M T-1538$ & Lepa & $\mathrm{P}$ & $\mathrm{Lf}$ & $\begin{array}{l}\text { RBC: The hunted deer (Hidum) is packed with its leaves in } \\
\text { the local bag (Tali) so that deer's departed soul can't harm } \\
\text { the hunter }\end{array}$ & $\mathrm{N}$ & 0.017 \\
\hline Wallichia triandra (J.Joseph) S.K.Basu [Arecaceae]; MT-1537 & Taleng & $\mathrm{P}$ & Lf & RBC: Same as for Wallichia oblongifolia & $\mathrm{N}$ & 0.017 \\
\hline Youngia japonica (L.) DC. [Asteraceae]; MT-1536 & Rungdum & HA & Lf & Mst: Dried leaves as a substitute for tobacco & $\mathrm{N}$ & 0.017 \\
\hline Zanthoxylum armatum DC. [Rutaceae]; MT-1535 & Ombeng & $\mathrm{S}$ & Fr, Lf, St & $\begin{array}{l}\text { F: Fruits and leaves as a spice; M: twigs as toothbrush } \\
\text { during toothache }\end{array}$ & $\mathrm{N}$ & 0.034 \\
\hline Zanthoxylum oxyphyllum Edgew.[Rutaceae]; MT-1534 & Onger & $\mathrm{L}$ & $\mathrm{Lf}, \mathrm{Br}$ & $\begin{array}{l}\text { F: Leaves as a condiment; Fh: Bark paste for fish } \\
\text { stupefaction }\end{array}$ & $\mathrm{N}$ & 0.034 \\
\hline Zanthoxylum rhetsa (Roxb.) DC. [Rutaceae]; MT-1533 & Onger & $\mathrm{T}$ & $\mathrm{Lf}, \mathrm{Br}$ & $\begin{array}{l}\text { F: Leaves as a condiment; } \\
\text { Fh: Bark paste for fish stupefaction }\end{array}$ & $\mathrm{N}$ & 0.034 \\
\hline Zingiber officinale Roscoe [Zingiberaceae]; MT-1532 & Takeng & HG & $\mathrm{Rh}$ & $\begin{array}{l}\text { F: Most common condiment; M: warmed rhizome paste } \\
\text { applied on infected wounds for fast healing }\end{array}$ & $\mathrm{N}$ & 0.034 \\
\hline Zingiber sianginensis Tatum \& A.K. Das [Zingiberaceae]; MT-1531 & Ke-kiir & HG & $\mathrm{Rh}$ & $\begin{array}{l}\text { F: Common condiment; M: In cough, stomachache, and } \\
\text { vomiting raw rhizome orally; RBC: rhizome paste applied } \\
\text { on the body to keep away the evil spirits and snakes by its } \\
\text { aroma while in the jungle }\end{array}$ & $\mathrm{N}$ & 0.051 \\
\hline
\end{tabular}

